\title{
Hyaline Membrane Disease
}

\section{I: Cellular Changes}

\author{
GILLIAN GANDY, W. JACOBSON, * and DOUGLAS GAIRDNER \\ From The Strangeways Research Laboratory, and the Cambridge Maternity Hospital
}

Gandy, G., Jacobson, W., and Gairdner, D. (1970). Archives of Disease in Childhood, 45, 289. Hyaline membrane disease. I: Cellular changes. Cellular changes were studied in $1 \mu$ thick sections of lungs from 84 perinatal deaths, including 44 with hyaline membrane disease (HMD). The presence or absence of osmiophilic granules was related to surface tension measurements in 69 cases. The presence of numerous granules usually indicated normal surfactant and their absence a lack. It is concluded that the granules represent surfactant material.

Osmiophilic granules were found first at 20 weeks' gestation (in 2 out of 6 fetuses). After 24 weeks' gestation almost all infants had many granules, except those with HMD.

The earliest stages in hyaline membrane formation consisted of interstitial oedema accompanied by localized areas of necrosis and desquamation of alveolar epithelial cells. Osmiophilic granules were virtually absent.

Infants dying at a later stage of the disease showed more extensive hyaline membranes, but from 36 hours almost all cases displayed some signs of repair of the denuded alveolar surfaces. In 5 out of 10 cases with evidence of repair, normal values for surface tension were obtained.

In the late stages of HMD some of the cells lining the alveoli were highly abnormal. They consisted of large thick squames with very few capillaries in apposition to them; the appearances were thus consistent with a severe degree of alveolo-capillary block.

Since the discovery of lung surfactant, much attention has been focused on the osmiophilic inclusions found in normal alveolar epithelium, since these are thought to be related to the synthesis or storage of surfactant. Most studies of the inclusions have been based on observations made by electron microscopy, but they are well shown under the light microscope, particularly if $1 \mu$ sections are employed.

Specimens of lung tissue were obtained immediately after death from fetuses, and from infants dying in the perinatal period, both with and without hyaline membrane disease (HMD). The presence or absence of the inclusions was correlated with normal development of the lung, pathological processes, and measurements of pulmonary surfactant. We were also able to study the cellular changes in HMD at ages ranging from a quarter of an hour to several weeks after birth.

Received 27 November 1969.

$\star$ Sir Halley Stewart Research Fellow.

\section{Material and Methods}

A total of 84 infants was studied; 68 were born alive, and 16 were stillborn, including 6 aborted fetuses of 20 weeks' gestation or less. The gestational age ranged from 15-40 weeks and birthweight from $0 \cdot 15-3 \cdot 48 \mathrm{~kg}$. Intrauterine death of the fetuses and stillborn infants was known to have occurred within 30 minutes of birth in all except one case which died approximately 6 hours before birth. The age at death of the 68 liveborn infants varied from 15 minutes to 5 weeks, but all except 7 were aged 3 days or less. 44 infants presented with the clinical signs of respiratory distress syndrome (RDS) and all except one had hyaline membranes (HM) at necropsy, the exception being an infant that survived for 5 weeks on a respirator. There were 24 liveborn infants who died from causes other than HMD.

The following post-mortem studies were performed: in all instances small fragments of lung were obtained through a thoracotomy shortly after death (usually within half an hour). The fragments were fixed immediately, and subsequently $1 \mu$ sections were examined under the light microscope (see methods); in $69 / 84$ cases slightly larger pieces of lung were taken 
at the same time for paraffin embedding and conventional histology. Full necropsy was carried out 1 to 3 days after death in 65 instances, the body being kept refrigerated in the interval; either the whole of one lung or a $5 \mathrm{~g}$. piece was then available for surfactant measurements, the majority of which were made within 5 days of death (maximum 10 days); in most cases material for routine histological sections was also obtained.

Histological studies ( $1 \mu$ thick sections). The fragments of lung obtained immediately after death were fixed at $4{ }^{\circ} \mathrm{C}$. for $12-24$ hours in $2.5 \%$ glutaralde-

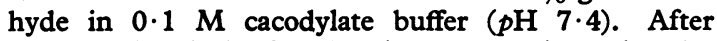
being washed in buffer, the pieces were trimmed under a dissecting microscope to small cubes with about $2 \mathrm{~mm}$. sides. Secondary fixation in $1 \%$ osmium tetroxide, buffered with veronal/acetate $p \mathrm{H} \quad \mathbf{7 \cdot 4}$ (Zetterqvist fixative), was carried out for 2 hours at $4{ }^{\circ} \mathrm{C}$. The tissue was dehydrated with ascending grades of ethanol or in 3 changes of a mixture of equal parts of methyl alcohol and monomethyl ethylene glycol; it was then placed in a mixture of equal parts of ethanol (or the methanol-monomethyl ethylene glycol mixture) and propylene oxide $(15 \mathrm{~min}$.), followed by pure propylene oxide $(15 \mathrm{~min}$.$) . The tissues were infiltrated with$ epoxy resin by leaving them for half an hour in a mixture of equal parts of propylene oxide and epoxy resin (Araldite), followed by 2 changes of pure Araldite for 6-18 hours each. The blocks were embedded in gelatin capsules filled with Araldite which was then polymerized by baking at $60^{\circ} \mathrm{C}$. for 48 hours. At least 5 blocks were prepared from each specimen.

Sections $1 \mu$ in thickness were cut on a Huxley microtome with glass knives, and floated out on $10 \%$ acetone in water. Wrinkles in the plastic were flattened by means of chloroform vapour. The sections were transferred to a drop of water on a clean glass slide and dried on a hot-plate at $45^{\circ} \mathrm{C}$. for half an hour.

The most satisfactory stains were found to be first, periodic acid-Schiff (PAS), followed by $1 \%$ Azur II and, secondly, $0.5 \%$ aqueous $\mathrm{p}$-phenylene diamine (Estable-Puig, Bauer, and Blumberg, 1965).

Periodic acid-Schiff $(P A S)$. The sections were treated with $1 \%$ aqueous periodic acid for 20 minutes, and rinsed in distilled water. They were then placed in Schiff's reagent for 1 hour, followed by 3 changes of freshly prepared $0.5 \%$ sodium hydrogen sulphite in $0.05 \mathrm{~N} \mathrm{HCl}$ for 2 minutes each. After being rinsed again in distilled water, the sections were stained in $1 \%$ aqueous Azur II for 24 hours, rinsed in distilled water for 15-30 minutes and air dried.

$p$-phenylene diamine. The sections were stained in the dark, using a freshly prepared and filtered $0.5 \%$ solution of p-phenylene diamine (BDH), the slides were then rinsed in 3 changes of distilled water for 1-3 minutes each and air dried. Before being mounted the sections were examined under the microscope; if a crystalline deposit was present, due to decomposition of the stock p-phenylene diamine, this could sometimes be removed by dipping the slide briefly into $1 \%$ acetic acid followed by $95 \%$ ethanol.
After being dried in air, the stained sections were mounted in DPX (G. T. Gurr). In addition to generaf histological examination under the light microscope $\overrightarrow{\overrightarrow{2}}$ particular attention was paid to the presence or absence of specific osmiophilic granules both within alveolare epithelial cells and lying free in the alveoli; these $\frac{0}{N}$. granules correspond to the lamellar inclusions seen in? electron micrographs (see Discussion). With PAS/ $\mathscr{Q}_{\mathscr{Q}}$ Azur II, the granules were coloured magenta against an blue cellular background and with p-phenylene diamines they were black against a light brown cellular back- $\overrightarrow{0}$ ground. The presence of the osmiophilic granules $\overrightarrow{-}$ was graded on a scale from $0-3+$. This was based on $\omega_{-}$ observations made on at least 5 sections, but usually 20 , mounted on several slides. The grading was as follows:융 $0=$ absent, $1+=$ occasional, $2+=$ scattered areas of numerous granules, $3+=$ numerous granules in almost all areas of the sections. This assessment was checked independently by 2 observers (G.G. and W.J.).

Surfactant measurements. The minimum surface tension $\left(T_{\min }\right.$.) of saline lung extracts was measured? in 69/84 cases. In addition, the stability of bubbles expressed from lung tissue was examined in 56/84 cases ; the presence or absence of bubble 'clicking' was noted $\bar{\Phi}$ in all 56, the bubble stability ratio (SR) was determinedin 40 cases. The methods used for these measurements were those previously described (Gandy et al., 1968).

\section{Results}

The material was arranged into 4 groups on the basis of the clinical signs and the findings at necropsy.

Group I: 16 stillborn infants.

Group II: 17 liveborn infants who died without $\stackrel{3}{\ulcorner}$ respiratory distress and without pathological changes in the lungs.

Group III: 7 liveborn infants whose death was associated with a variety of respiratory conditions:such as severe birth asphyxia, pulmonary haemor - . rhage, and congenital anomalies involving the lungs. $\delta$ They did not have typical signs of RDS and hyaline membranes were not found at necropsy.

Group IV: 44 liveborn infants who clinically had typical RDS, all except one having hyaline membranes at necropsy.

Groups I and II were regarded as 'controls', N showing the normal development of the lung, and 0 the effect of respiration. Group III represented aN mixed class of infants with pulmonary disorders 0 other than HMD. The ranges of gestational and postnatal ages and birthweights for the 4 groups are given in Table I, along with the number of $\stackrel{?}{+}$ cases in which surfactant was measured. The individual cases are shown diagrammatically in Fig. $10^{\circ}$ with the stillbirths (Group $I=x$ ) shown on the ordinate in ascending order of maturity. The live- $\frac{\vec{\Phi}}{\mathbb{Q}}$

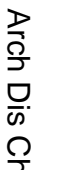


TABLE I

Gestational Age, Birthweight, and Surfactant Measurements in 4 Groups of Infants

\begin{tabular}{|c|c|c|c|c|}
\hline Group & $\underset{\text { Stillbirths }}{\text { I }}$ & $\begin{array}{l}\text { II } \\
\text { Liveborn Infants with } \\
\text { No Lung Pathology }\end{array}$ & $\begin{array}{c}\text { III } \\
\text { Liveborn Infants with } \\
\text { Pulmonary Disorders } \\
\text { Other Than Hyaline } \\
\text { Membrane Disease }\end{array}$ & $\begin{array}{c}\text { IV } \\
\begin{array}{c}\text { Hyaline Membrane } \\
\text { Disease }\end{array}\end{array}$ \\
\hline $\begin{array}{l}\text { Gestational age (range in weeks) } \\
\text { Postnatal age (range) } \\
\text { Birthweight (range in kg.) } \\
\text { No. of cases in each group (total 84) } \\
\text { Tmin. determinations (total 69) } \\
\text { Bubble stability determinations (total 56) } \\
\text { No. of cases without surfactant measure- } \\
\quad \text { ments (total 10) }\end{array}$ & $\begin{array}{c}15-40 \\
- \\
0 \cdot 15-3 \cdot 27 \\
16 \\
7 \\
9 \\
6\end{array}$ & $\begin{array}{c}24-40 \\
0 \cdot 72-3 \cdot 48 \\
17 \\
13 \\
11 \\
2\end{array}$ & $\begin{array}{c}24-40 \\
2-48 \mathrm{hr} \\
0 \cdot 74-3 \cdot 64 \\
7 \\
7 \\
6 \\
0\end{array}$ & $\begin{array}{c}24-40 \\
\frac{1}{2} \text { hr. }-7 \text { dy. } \\
\text { (and } 1 \text { of } 5 \text { wk.) } \\
0 \cdot 75-3 \cdot 35 \\
44 \\
42 \\
30 \\
2\end{array}$ \\
\hline
\end{tabular}

births (Group II $=0$, Group III $=\oplus$, and Group IV $=9$ ) are indicated on the horizontal lines according to maturity and postnatal age.

Cytological development of normal lung. The normal development of the lung and the changes produced by breathing at different stages of maturity must be defined before the pathology of HMD can be interpreted. Furthermore, because the presence of inclusions in the alveolar epithelial cells is related to that of surfactant, it is important to know when each of these first appears.

Specimens were available from 33 aborted fetuses, fresh stillbirths, and liveborn infants dying from non-pulmonary causes (Groups I and II). Two main lines of development take place in the lung from the 4th to the 9th month of gestation. First, while some of the columnar and cuboidal epithelial cells lining the primitive ducts continue to proliferate and form new terminal buds, other cuboidal cells differentiate into the very thin squamous cells which constitute the predominant cell population of the functioning air space at term. Secondly, the capillaries, which are scanty at first, increase in number and grow into close apposition to the flattened epithelial cells thus forming the

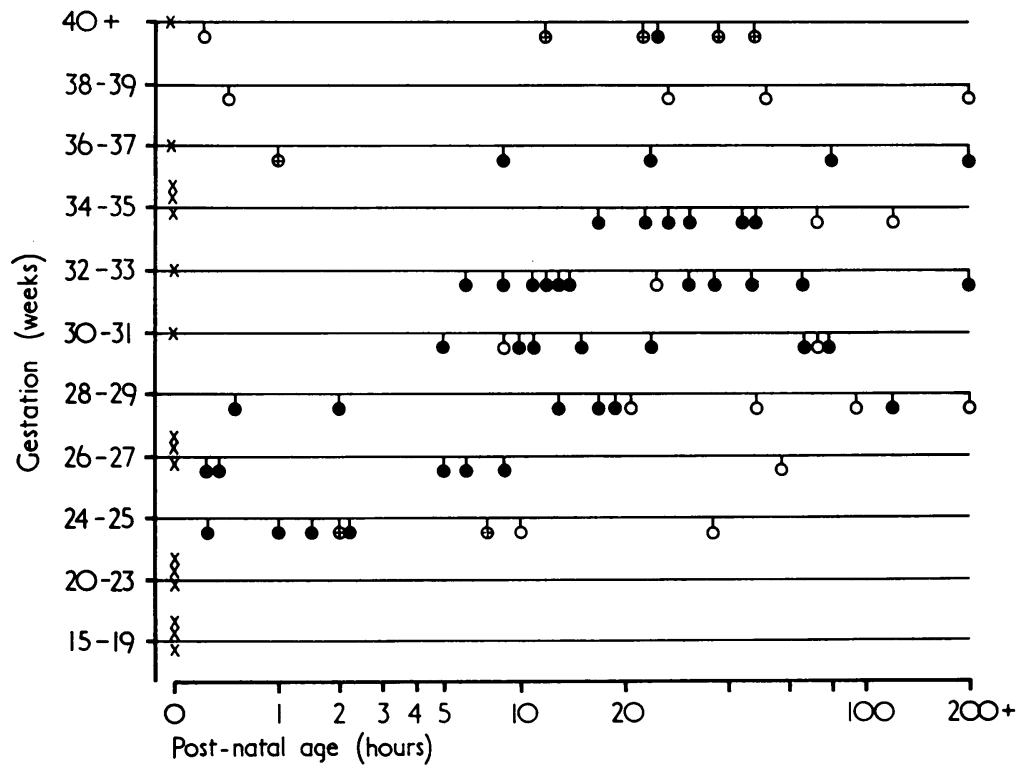

FIG. 1.-Gestational and postnatal ages of 84 infants. $\quad \times=$ Group I, stillborn infants; $O=$ Group II, liveborn infants without pulmonary disorders; $\oplus=$ Group III, liveborn infants with pulmonary disorders other than HMD; and $=$ Group IV, liveborn infants with $H M D$. 


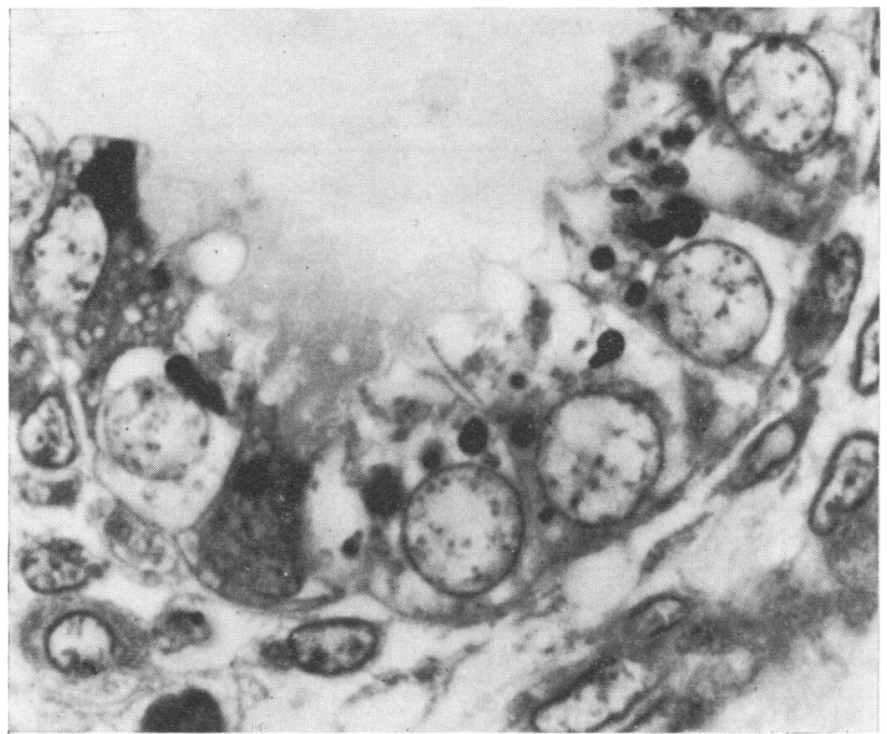

Frg. 2.*-Lung from a 20-week fetus. Note uniform cuboidal epithelium forming the wall of a primordial alveolar duct Osmiophilic granules appear black, glutaraldehyde-Os $\mathrm{O}_{4}$ fixation; stained with p-phenylene diamine $(\times 1,400) \subseteq$

*Fig. 2-17 are all of $1 \mu$ sections.

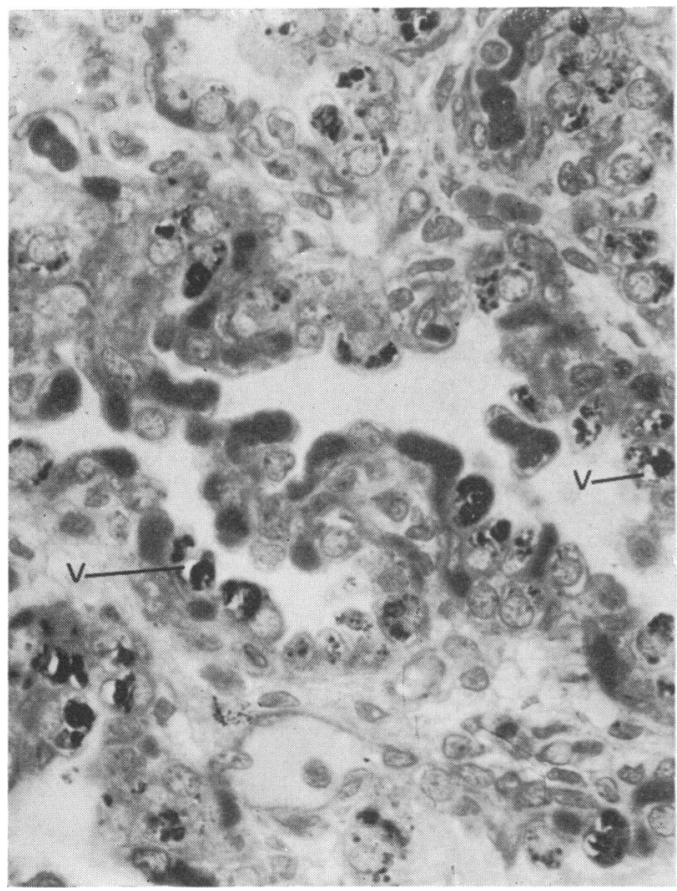

Fig. 3a.- Lung from a 26-rveek fetus showing flattened epithelial cells covering capillaries (filled with tightly packed red cells stained almost black). Cuboidal cells, frequently containing osmiophilic granules, are interspersed. Many of the granules are enclosed in a vacuole (v). Technique as in Fig. 2. ( $\times$ 450.) Surfactant abnormal.

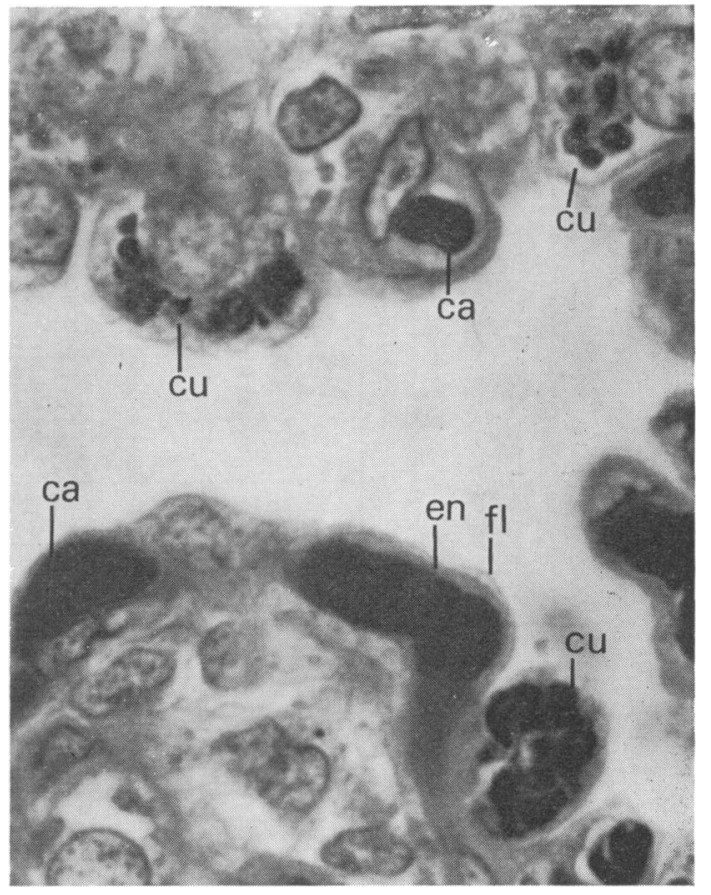

FIG. 3b.-An area of Fig. 3a under higher magnification showing cuboidal cells (cu), flattened cells $(f)$, and capil $\stackrel{0}{-}$ laries with red cells (ca); the cytoplasm of a capillaryo endothelial cell (en) is indicated. $(\times 1,400$. 
blood/air barriers. These two lines of development will now be described.

Epithelial cells. At 15 weeks the lung parenchyma consisted of ducts and terminal buds lined by a low columnar or cuboidal epithelium, and the characteristic osmiophilic inclusions or granules had not yet appeared. At 20 weeks the terminal buds, which had a 'rosette like' appearance in cross-section, were composed of a uniform cuboidal epithelium and no flattened cells were present.* This was the earliest stage at which the characteristic osmiophilic inclusions or granules were found.

*The nomenclature of the alveolar epithelial cells is confused but there are in fact only two types. The first is the flattened (squamous) form with an attenuated cytoplasm covering the capillaries and thus forming the blood/air barriers; this cell corresponds to the membranous pneumonocyte described by Macklin (1954), and is sometimes called a Type I cell (Karrer, 1956). The second type, which is cuboidal in shape and corresponds to the granular pneumonocyte of Macklin, contains characteristic osmiophilic inclusions (or granules); it is sometimes called the great alveolar cell, or large pulmonary alveolar cell, or Type II cell. In this paper the two types will simply be referred to as flattened and cuboidal.

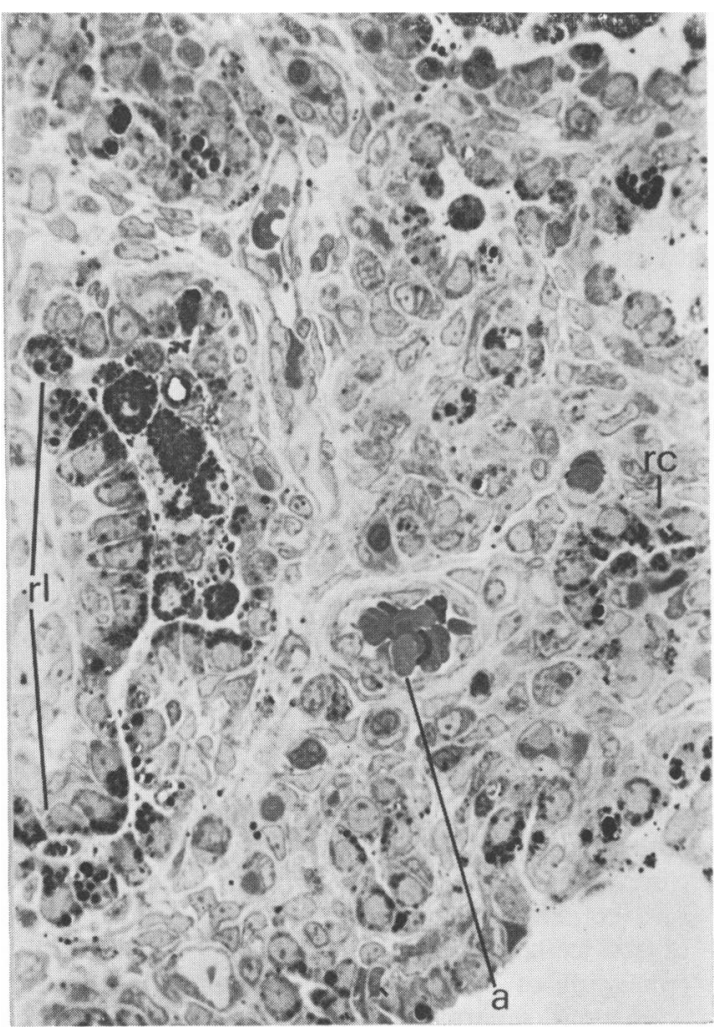

Fig. 4a.-Lung from a 24-week infant who lived 36 hours. Note prominent connective tissue and a dilated arteriole (a). One terminal bud (rosette) is cut in longitudinal section $(r l)$, others are shown in cross-section $(r c)$. The cuboidal cells contain many granules. Technique as in Fig. 2. ( $\times$ 480.) Surfactant normal.
They were present in 2 out of 6 fetuses at 20 weeks' gestation; in one case there were only a very few, but in the other they were quite numerous (Fig. 2). These intracytoplasmic granules were strongly osmiophilic and PAS positive.

The first flattened cells, initially few in number, were found at 24-26 weeks' gestation; they occurred as individual cells interspersed between cuboidal cells (Fig. 3a and b), and intermediate forms were also seen. The intracytoplasmic granules in the cuboidal cells were numerous by this stage; sometimes the lamellar structure of the inclusions could be clearly discerned, and often they were enclosed within a vacuole (Fig. 3a). The 2 lungs from stillbirths (26 weeks' gestation) showed very few extracellular granules in the potential air spaces. In contrast, the lungs of infants of 24 weeks' gestation who survived more than 9 hours had well-dilated air spaces with many extracellular osmiophilic granules (Fig. 4a), some of which

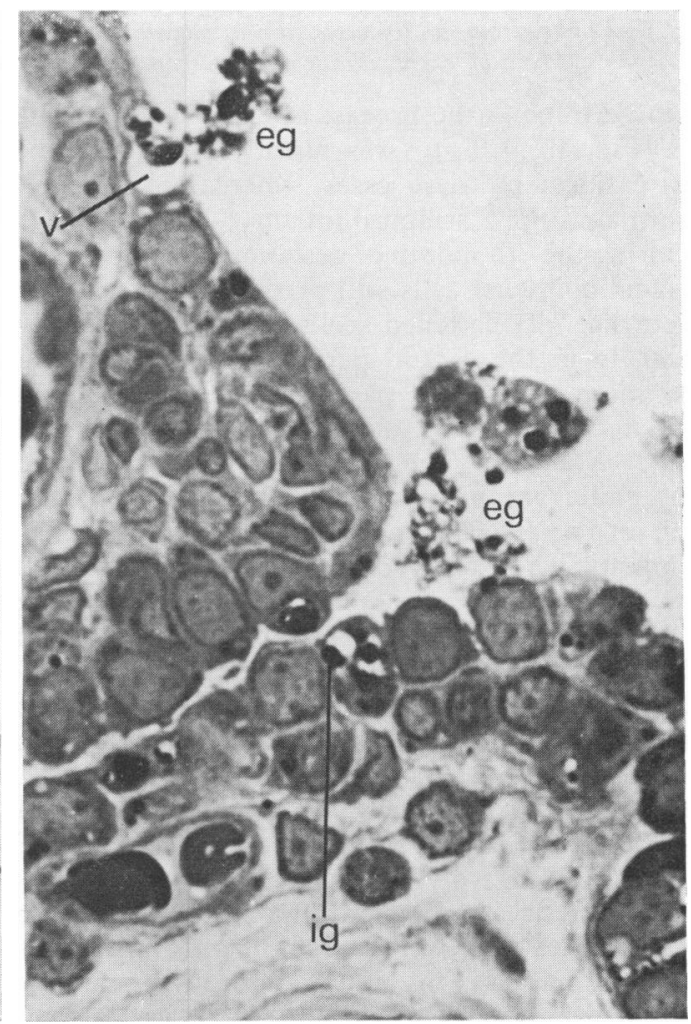

Fig. 4b.-Same specimen as Fig. 4a, showing extracellular granules (eg), intracellular granules in vacuoles (ig). Some granules apparently are being discharged from a vacuole $(v) . \quad(\times 1,200$. 


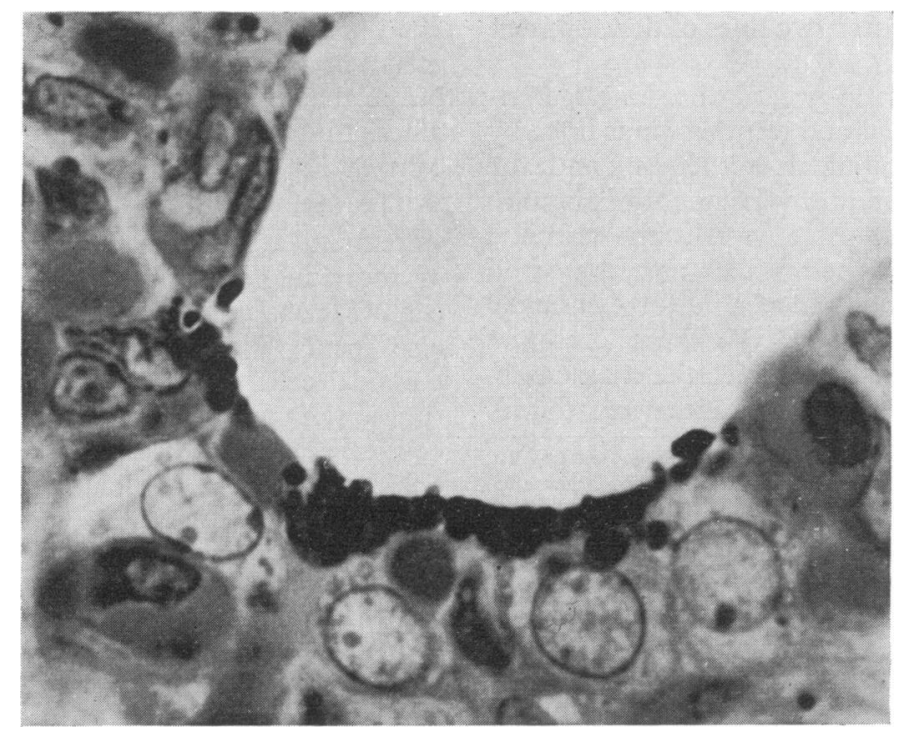

FIG. 5.-Lung from a 30-week infant who survived 8 hours. A group of cuboidal epithelial cells is covered by a layer of extracellular granules on the alveolar surface. Technique as for Fig. $2 . \quad(\times 1,500$.

appeared to be in the process of extrusion from the cells (Fig. $4 b$ ). $T_{\min }$. was already normal in the lung extracts of these cases, whereas it was still abnormal in the 2 stillborn infants.

During the 7th month of gestation (28-32 weeks), cuboidal epithelial cells still predominated, but the proportion of flattened cells increased steadily especially in the central part of the lung lobules. The more peripheral parts, however, were still composed of rosettes of cuboidal cells (terminal buds). Many of the cuboidal cells contained osmiophilic granules which sometimes formed a layer on the alveolar surface (Fig. 5). The lungs of infants who survived for longer periods (5-8 days) had rather fewer granules than those living for 1-2 days. In a set of twins that survived 2 and 8 days, respectively, little difference in the appearances of their lungs was observed, indicating that few structural changes take place during the first week of life.

During the last 2 months of gestation, flattened alveolar epithelial cells became more numerous. Among the lungs of stillbirths there were conspicuous differences in the distribution of the granules: in some cases they were predominantly intracytoplasmic (Fig. 6), in others almost completely extracellular (Fig. 7), and in others again they occurred intra- and extracellularly in approximately equal numbers. Thus it appears that granules can be discharged into the potential air spaces before the onset of respiration. Two specimens were obtained from full-term infants who died within half an hour of birth; the lungs $\vec{e}$ were well expanded, there were many granules. lying free in the air spaces, and the cuboidal cells contained both granules and vacuoles, as though the latter had just discharged some of their materialo (Fig. 8). The appearances in older infants wereo essentially similar.

Development of capillaries. Before the 20th week 3 of gestation the capillaries are not in direct contact with the epithelial cells lining the ducts, but are separated from them by loosely arranged fibroblasts. From about the 24th week onwards, a few capillaries were found in close apposition to flattened epithelial cells, so that the endothelial cells. of distended capillaries, covered by the attenuated 0 cytoplasm of flattened epithelial cells, protruded $₹$ into the lumen of the potential air spaces. The 옥 basement membrane between the epithelium and $>$ underlying endothelium was so thin that it could only be seen as a fine line under good optical f conditions at high magnification (see Fig. 3b). Such protruding capillaries, forming the blood/air O barriers, initially constituted only a small proportion $\mathbb{N}^{N}$ of the cells lining the air spaces, the remainder consisting of cuboidal cells; at this stage the ductso were well separated from each other by a loose $\frac{\mathcal{D}}{\mathscr{}}$ mesenchyme (Fig. 3a). By 34 weeks' gestation the $\stackrel{?}{+}$ capillary network under the sheets of flattened 0 cells was well developed (Fig. 6 and 7), and the connective tissue septa became progressively thin- $\stackrel{\square}{\square}$ ner as gestation advanced (Fig. 8). 


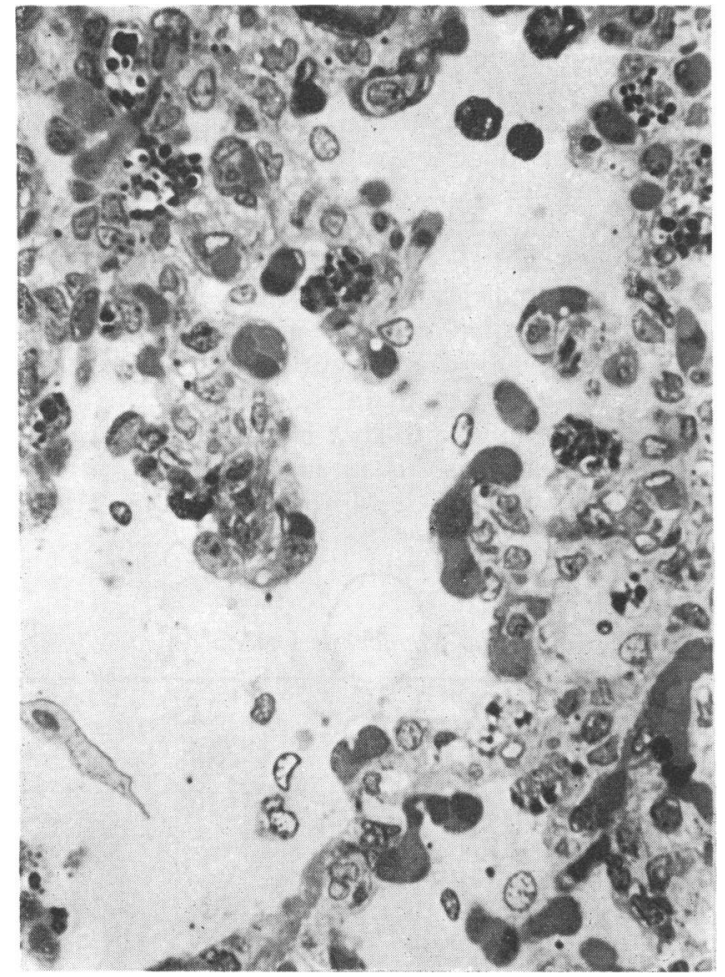

FIG. 6

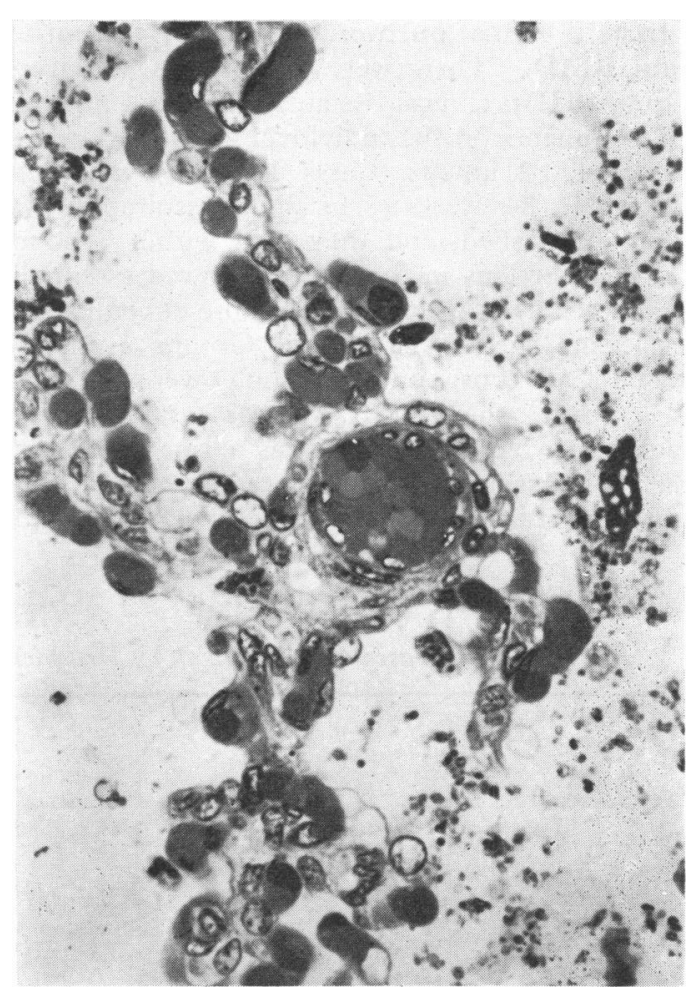

FIG. 7
FIG. 6.-Lung section of a stillborn infant (34-week gestation). Note well-expanded air spaces lined by predominantly flattened epithelium. This covers capillaries protruding into the lumen when they are filled with red cells (dark grey). Osmiophilic granules are mainly intracellular (in the cuboidal cells). Technique as in Fig. 2. ( $\times$ 480. $)$ Surfactant normal.

FIG. 7.-Lung from a stillborn infant (34-week gestation). In the centre is a dilated arteriole. The alveolar septa are thin, and capillaries, filled with darkly stained red cells, are conspicuous. Osmiophilic granules are predominantly extracellular, in contrast to Fig. 6. Technique as in Fig. 2. $(\times 480$. $)$ Surfactant normal.

FIG. 8.-Lung from a full-term hydrocephalic infant, age 15 minutes; this shows the normal appearance of the lung very soon after birth. Note protruding capillaries (ca) covered by the attenuated cytoplasm of flattened epithelial cells. Cuboidal epithelial cells containing granules (cu) can also be seen. There are abundant extracellular granules (eg) lying free in the alveoli. Technique as in Fig. $2 .(\times 450$.$) Surfactant normal.$

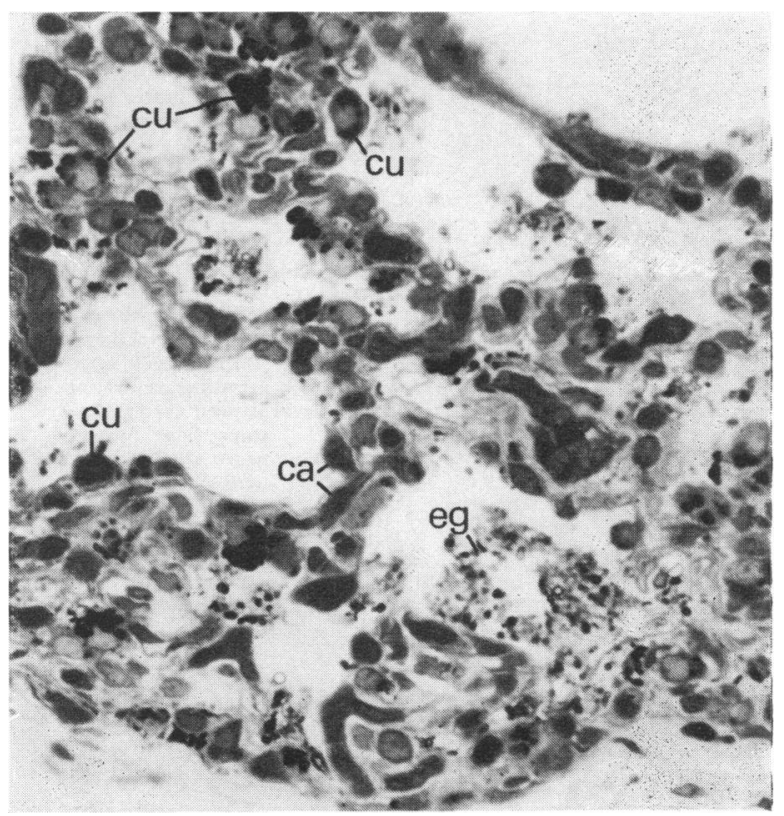

FiG. 8 
Infants with pulmonary conditions other than HMD. There were 7 infants in this group (Group III); clinical details, necropsy findings, and comments on the individual cases are given in Table II. 2 infants (Cases 1 and 2) were very immature (24 weeks), sustained respiration was never established, and they died within 7 hours. The $1 \mu$ sections in these cases showed essentially similar cellular development to those of comparable gestational age in the control Groups I and II. In one (Case 2) osmiophilic granules were numerous $(2+)$ and, though $T_{\min }$ was abnormal (19 dynes/cm.), bubble stability was normal, indicating that some surfactant was present. The other immature infant (Case 1) differed from the control group in that only a few $(1+)$ granules were present, and both $T_{\min }$ and bubble stability were abnormal. It is possible that this case was a candi- $\overrightarrow{\vec{F}}$ date for HMD, and that membranes could not yet be discerned at 2 hours of age even in the $1 \mu$ 등 sections.

Four infants in this group (Cases 3-6) were $\frac{\bar{\phi}}{\bar{\phi}}$ born at term, all were severely asphyxiated at birth $\propto$ and required prolonged resuscitation with inter- $\%$ mittent positive pressure ventilation (IPPV); all $\overrightarrow{0}$ had signs of severe neurological damage. The $\vec{\exists}$ cellular development in the lungs of these infants $\vec{\omega}$ was again similar to that in the control group; all showed moderate to severe interstitial pulmonary 응 haemorrhage. In 2 of these 4 (Cases 3 and 4),

TABLE II

7 Cases with Respiratory Disorders other than Hyaline Membrane Disease

\begin{tabular}{|c|c|c|c|c|c|c|c|c|}
\hline $\begin{array}{l}\text { Case } \\
\text { No. }\end{array}$ & $\begin{array}{l}\text { Gest. } \\
\text { (wk.) }\end{array}$ & $\begin{array}{l}\text { Age at } \\
\text { Death } \\
\text { (hr.) }\end{array}$ & $\begin{array}{l}\text { Birth- } \\
\text { weight } \\
\text { (kg.) }\end{array}$ & Clinical & Nezropsy & $\begin{array}{l}\text { Tmin. } \\
\text { (dynes/ } \\
\text { cm.) }\end{array}$ & $\begin{array}{c}\text { Granules } \\
\text { (grading } \\
0-3+\text { ) }\end{array}$ & Remarks \\
\hline 1 & 24 & 2 & $0 \cdot 74$ & Gasping respiration only & Immature lung & 27 & $1+$ & $\begin{array}{l}\text { Abnormal bubble } \\
\text { stability; pos- } \\
\text { sible candidate } \\
\text { for HMD }\end{array}$ \\
\hline 2 & 24 & 7 & 0.57 & Gasping respiration only & Immature lung & 19 & $2+$ & $\begin{array}{l}\text { Normal bubble } \\
\text { stability }\end{array}$ \\
\hline 3 & 40 & 38 & $3 \cdot 64$ & $\begin{array}{l}\text { CS for transverse lie; } \\
\text { grand multip.; condition } \\
\text { poor at birth ( } p \mathrm{H} 6 \cdot 76) \text {; } \\
\text { treated with IPPV and } \\
\mathrm{NaHCO} \mathrm{C}_{3} \text {; never became } \\
\text { pink }\end{array}$ & $\begin{array}{l}\text { Interstitial pulmonary } \\
\text { haemorrhage }\end{array}$ & 13 & $2+$ & \\
\hline 4 & 40 & 48 & $3 \cdot 29$ & $\begin{array}{l}\text { Normal delivery; poor } \\
\text { condition at birth; } \\
\text { breathed after } 10 \text { min.; } \\
\text { remained limp and un- } \\
\text { responsive; developed } \\
\text { apnoeic attacks and } \\
\text { convulsions }\end{array}$ & $\begin{array}{l}\text { Interstitial pulmonary } \\
\text { haemorrhage }\end{array}$ & 12 & $3+$ & \\
\hline 5 & 40 & 12 & $2 \cdot 35$ & $\begin{array}{l}\text { Fetal distress-slow FH; } \\
\text { meconium-stained } \\
\text { liquor; condition poor at } \\
\text { birth; } \mathrm{pH} 6 \cdot 83 \text {; spon- } \\
\text { taneous breathing after } \\
2 \mathrm{hr} \text {; remained cyanosed } \\
\left(\mathrm{Po}_{2} 32 \text { in } 100 \% \mathrm{O}_{2}\right) ; \\
\text { grunting respiration }\end{array}$ & $\begin{array}{l}\text { Intra-alveolar and } \\
\text { interstitial pulmo- } \\
\text { nary haemorrhage; } \\
\text { few granules but } \\
\text { many large vacuoles } \\
\text { in cuboidal cells } \\
\text { (see Fig. 9) }\end{array}$ & 7 & $1+$ & $\begin{array}{l}\text { Appearance of } \\
\text { large vacuoles } \\
\text { suggests that } \\
\text { granules had } \\
\text { all been } \\
\text { discharged }\end{array}$ \\
\hline 6 & 40 & 23 & $3 \cdot 21$ & $\begin{array}{l}\text { Prolapsed cord in } 2 \text { nd } \\
\text { stage; heart beat not } \\
\text { heard at birth; treated } \\
\text { with cardiac massage } \\
\text { and } \mathrm{NaHCO}_{3} ; \text { breathed } \\
\text { after } 1 \mathrm{hr} \text {. } \mathrm{pH} 6 \cdot 75 \text { at } 1 \frac{1}{2} \\
\text { hr.; improved to } \mathrm{pH} \\
7 \cdot 31 \text { at } 6 \mathrm{hr} \text {; developed } \\
\text { convulsions }\end{array}$ & $\begin{array}{l}\text { Interstitial pulmonary } \\
\text { haemorrhage }\end{array}$ & 21 & $2+$ & $\begin{array}{l}\text { Presence of } \\
\text { granules with } \\
\text { abnormal } \\
T_{\text {min. is }} \\
\text { exceptional }\end{array}$ \\
\hline 7 & 36 & 1 & $2 \cdot 28$ & $\begin{array}{l}\text { Apnoeic at birth; lungs } \\
\text { very difficult to inflate; } \\
\text { marked retractions; } \\
\text { never became pink }\end{array}$ & $\begin{array}{l}\text { Renal agenesis; hypo- } \\
\text { plastic lungs (com- } \\
\text { bined wt. = } 10 \mathrm{~g} ., \\
\text { expected wt. = } \\
40 \mathrm{~g} . \text { ); histologically } \\
\text { immature (similar } \\
\text { to } 24-26 \text { wk.) }\end{array}$ & 23 & $2+$ & $\begin{array}{l}\text { Normal bubble } \\
\text { stability }\end{array}$ \\
\hline
\end{tabular}

FH, fetal heart; CS, Caesarean section; IPPV, intermittent positive pressure ventilation. 


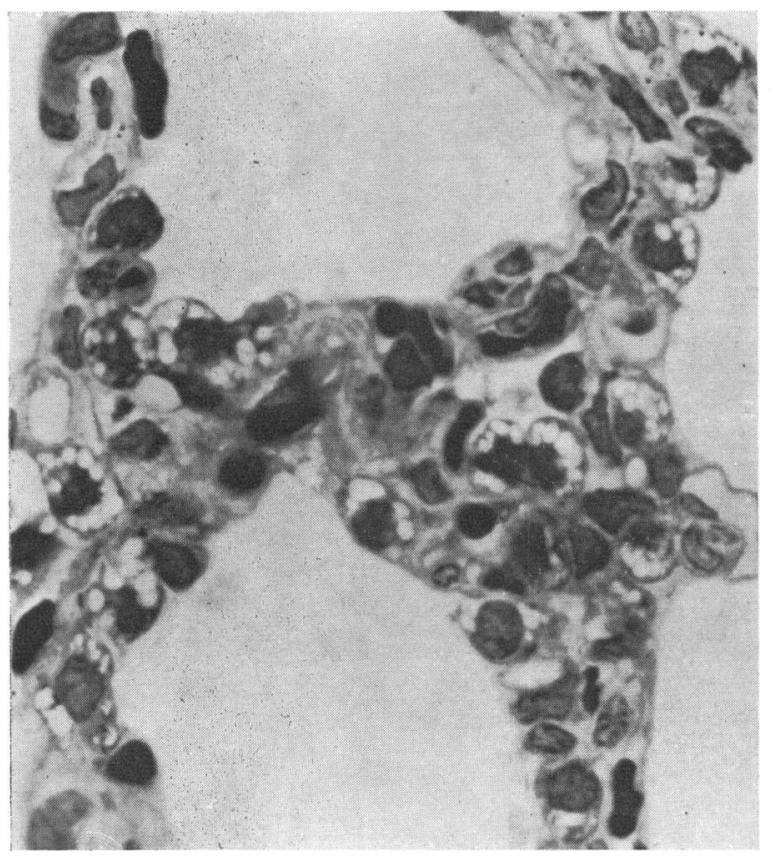

FIG. 9.-Lung from a full-term infant aged 12 hours (Case 5, Table II). Severely asphyxiated at birth (Apgar score 0). Spontaneous respiration only established after 2 hours. Note the large clear vacuoles in cuboidal epithelial cells and the absence of intra-and extracellular granules. Glutaraldehyde-Os $\mathrm{O}_{4}$ fixation, stained with PAS-Azur II. ( $.1,000$.) Surfactant normal. granules were plentiful and $T_{\min }$. was normal. The third case (Case 5) was of interest in that though there were relatively few granules, the cuboidal cells contained many large vacuoles, suggesting that the content of these vacuoles had been discharged into the air spaces (Fig. 9); $T_{\min }$. was normal in this case. In the fourth case (Case 6), $T_{\min }$. was abnormal despite the presence of many granules, a discordance that was not explained.

The last case in this group (Case 7), was of 36 weeks' gestation and lived for only 1 hour. At resuscitation the lungs were very 'stiff' to inflate. Necropsy revealed bilateral renal agenesis and hypoplastic lungs. Histologically the lung structure was immature, resembling that seen in infants of 24-26 weeks' gestation. Furthermore, $\mathrm{T}_{\mathrm{min}}$. was abnormal despite the presence of numerous granules, a picture resembling that already described in some very premature stillbirths (Group I).

The observations on stillbirths and infants dying from causes other than HMD (Groups I, II, and III) are summarized in Table III.

Infants with hyaline membrane disease. There were 44 infants in this group (Group IV); the gestational and postnatal ages are shown in Fig. 1. The course of the disease is described in the following stages, though no sharp dividing line separates them; particular attention was paid to the very early stages and also to the reparative phase.

TABLE III

Development of Lung Related to Surfactant

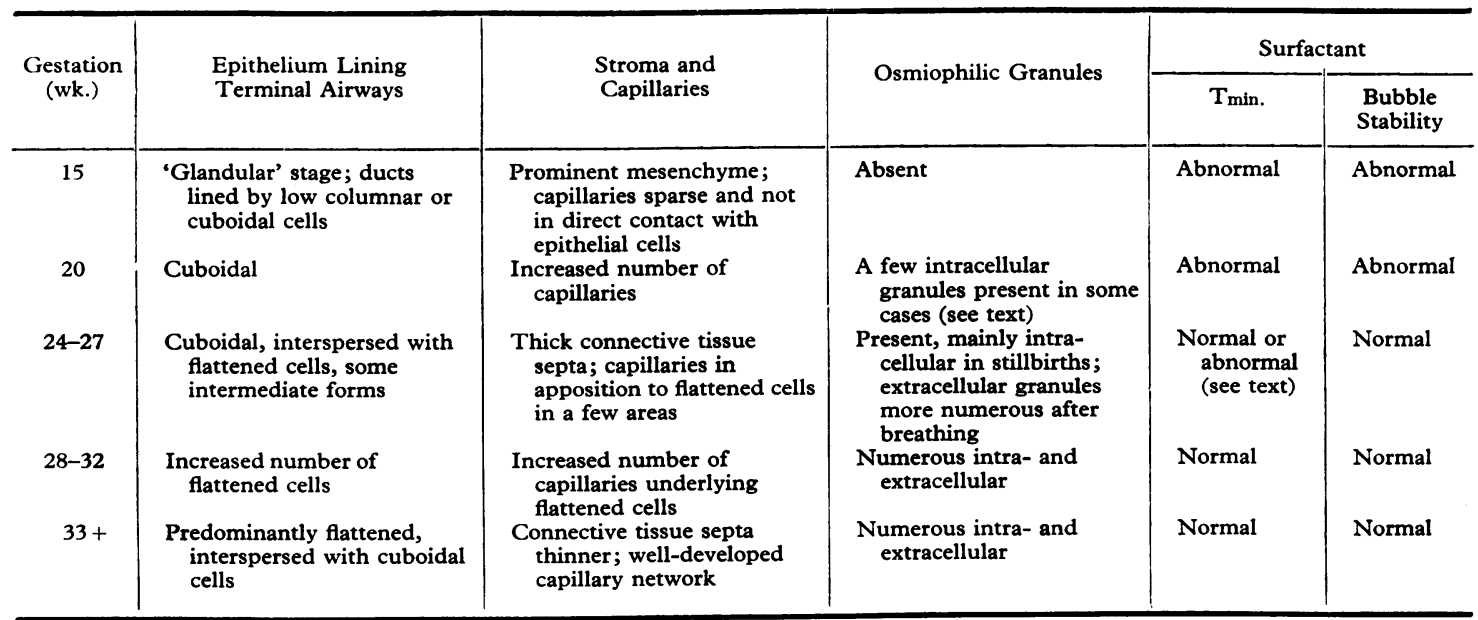




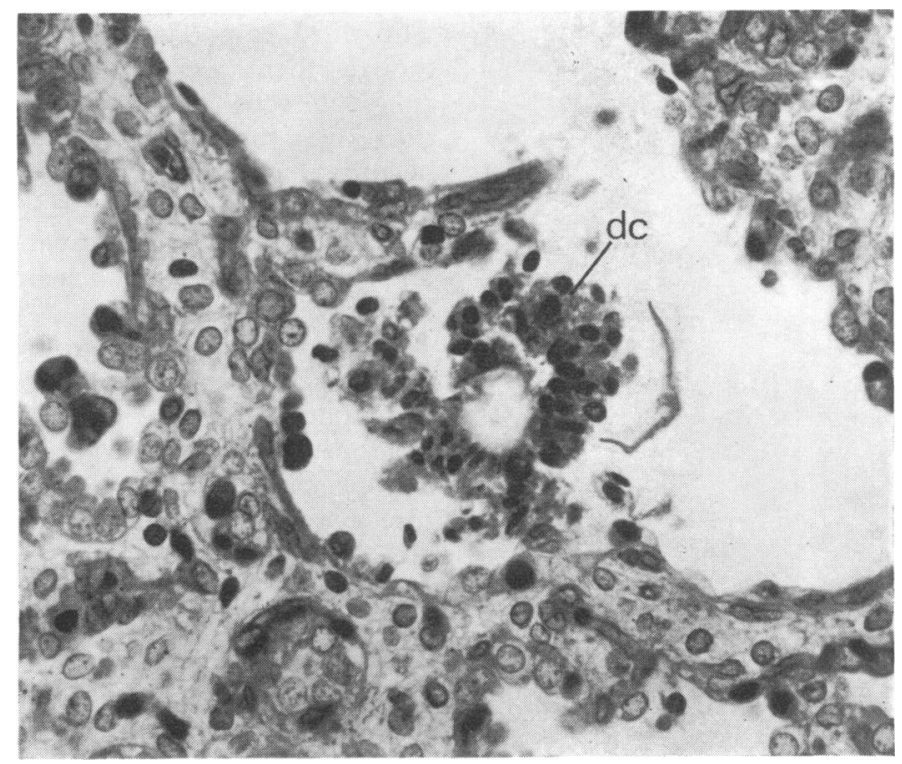

FIG. 10a.-Early HMD. Lung from an infant aged 15 minutes (Case 1, Table IV, 26 weeks' gestation). A clump of $\overrightarrow{0}$ desquamated alveolar epithelial cells (dc) lies free in an alveolar duct; note their pyknotic nuclei. Technique as in ${ }^{\circ}$ Fig. 2. ( $\times$ 550.) Surfactant abnormal.

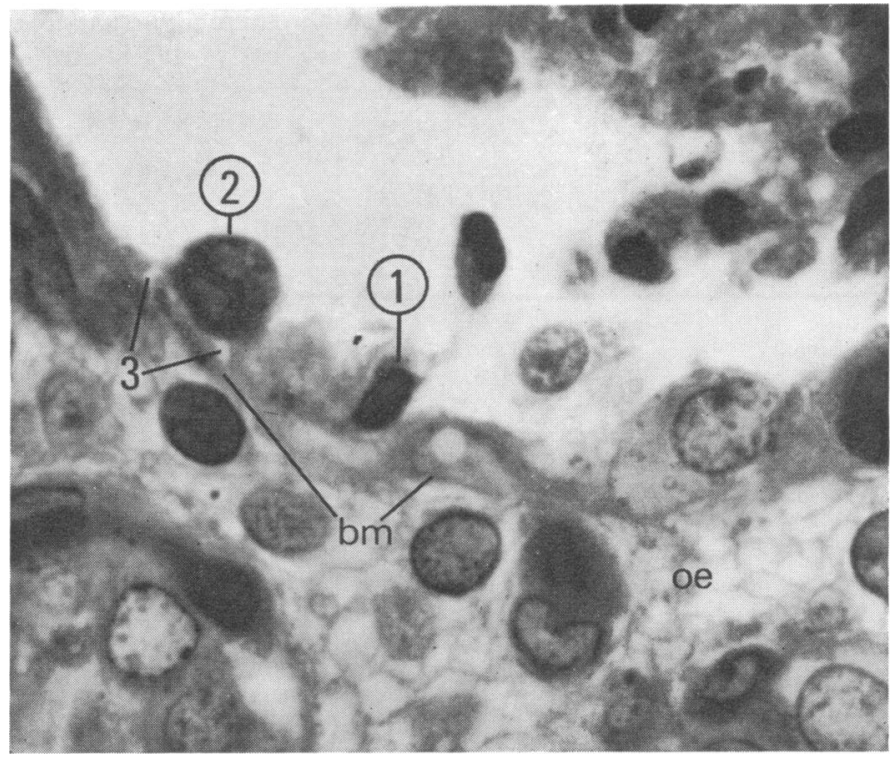

FIG. 10b.-An area of Fig. 10a under higher magnification. An epithelial cell $(1)$ is apparently being levered off by $\longrightarrow$ exudate. An adjacent epithelial cell (2) shows fluid-filled spaces (3) where it is becoming detached from the base- $\mathrm{O}$ ment membrane $(\mathrm{bm})$. There is marked interstitial oedema (oe). Osmiophilic granules are absent. Technique as in Fig. 2. $(\times 1,400$. 
(1) Early stages.

(2) Intermediate stages.

(3) The classic picture of fully developed HMD.

(4) Early reparative phases.

(5) Late changes after HMD.

Early stages. The earliest specimens obtained were from 8 infants who lived 2 hours or less (Table IV); 4 lived less than one hour and all were of 24-28 weeks' gestation. The cellular appearances were remarkably similar in all 8 cases; the lungs showed some areas of expansion and others of atelectasis, though the dilatation of alveolar ducts, so characteristic of later stages, was not always present. Some of the expanded air spaces were filled with fluid, the lymphatics were dilated, and pulmonary arterioles contracted. The terminal air spaces were lined by a mixed epithelium composed of both flattened and cuboidal cells. In spite of the early fixation, many alveolar epithelial cells were in process of becoming detached from a thickened basement membrane, and some were lying free in the lumen of alveolar ducts (Fig. 10a and $\mathrm{b}$ ); these cells were easily distinguished from the amniotic squames sometimes found in the lungs of infants dying in the perinatal period. The desquamation occurred usually in the form of individual cells, but here and there small groups or even sheets of cells became detached (Fig. 10a). In a few places the epithelium appeared to be replaced by short stretches of a homogeneous membrane, which was thought to represent the earliest phase of a hyaline membrane (Fig. 11 and 12). The interstitial tissues, i.e. fibroblasts and vasculature, were very oedematous and the cytoplasm of capillary endothelial cells, fibroblasts, and alveolar epithelium contained very fine vacuoles, corresponding to the larger pinocytotic vesicles seen in the electron microscope. Capillaries lying directly beneath hyaline membranes were filled with tightly packed red cells which had a 'sludged' appearance, but those bordering areas of normal alveolar epithelium were well dilated and contained plasma as well as discrete red cells (Fig. 12). Of the 8 cases, 6 showed no osmiophilic granules and 2 had only a very few $(1+$ ) (Cases 3 and 4 , Table IV). $T_{\text {min. }}$ was unequivocally abnormal $(\geqslant 23$ dynes/cm.) in all the 7 cases in which it was measured. Bubble clicking, determined in 5 cases, was abnormal in 4; one case (Case 4, Table IV) gave normal values, indicating that some surfactant was probably present.

Thus the earliest changes in HMD consisted of diffuse interstitial oedema, with epithelial cells becoming detached from a swollen basement membrane. Very small patches of HM overlaid the denuded areas. Osmiophilic granules were virtually absent. (Except for the desquamation, these changes were almost undetectable in conventional $8 \mu$ paraffin sections.)

Intermediate phase. Specimens obtained from infants who died 5-10 hours after birth showed more extensive involvement of alveolar ducts as well as local extension of the disease process; in otherwise uninvolved alveolar ducts, epithelial cells, singly or in groups, were becoming detached from their thickened basement membrane by an amorphous exudate. Other areas showed the disease in a more advanced phase with overdistended alveolar ducts and conspicuous hyaline membranes in which necrotic cells and nuclear debris were embedded

TABLE IV

8 Cases with Early Changes of Hyaline Membrane Disease

\begin{tabular}{|c|c|c|c|c|c|c|c|c|c|}
\hline $\begin{array}{l}\text { Case } \\
\text { No. }\end{array}$ & $\begin{array}{l}\text { Gest- } \\
\text { ation } \\
\text { (wk.) }\end{array}$ & $\begin{array}{c}\text { Birth- } \\
\text { weight } \\
\text { (kg.) }\end{array}$ & $\begin{array}{c}\text { Age } \\
\text { at } \\
\text { Death }\end{array}$ & Clinical & $\underset{\substack{\text { (grading } \\
1-3+\text { ) }}}{\text { HM }}$ & $\begin{array}{c}\text { Bubble } \\
\text { SR }\end{array}$ & $\begin{array}{c}\text { Bubble } \\
\text { Click }\end{array}$ & $\begin{array}{c}T_{\min .} \\
\text { (dynes/ } \\
\text { cm.) }\end{array}$ & $\begin{array}{c}\text { Granules } \\
\text { (grading } \\
0-3+\text { ) }\end{array}$ \\
\hline 1 & 26 & $1 \cdot 00$ & $15 \mathrm{~min}$. & Poor condition at birth; gasping respiration & $1+$ & 一 & $\mathbf{0}$ & 33 & 0 \\
\hline 2 & 27 & $0 \cdot 80$ & $15 \mathrm{~min}$. & $\begin{array}{l}\text { Twin } 1 \text { (both died); poor condition at birth; } \\
\text { gasping respiration }\end{array}$ & $1+$ & - & - & - & 0 \\
\hline 3 & 24 & 0.65 & $15 \mathrm{~min}$. & Poor condition at birth; gasping respiration & 1. & - & 0 & 38 & $1+$ \\
\hline 4 & 28 & $1 \cdot 34$ & $30 \mathrm{~min}$. & $\begin{array}{l}\text { Poor condition at birth; IPPV; gasping respiration } \\
\text { only }\end{array}$ & 1 & 0.89 & + & 23 & $1+$ \\
\hline 5 & 24 & $0 \cdot 70$ & $1 \mathrm{hr}$. & Poor condition at birth; gasping respiration & 1 & - & 0 & 24 & 0 \\
\hline 6a & 24 & 0.72 & $1 \frac{1}{2} \mathrm{hr}$. & $\begin{array}{l}\text { Twin 1: small antepartum haemorrhage; gasping } \\
\text { respiration }\end{array}$ & 1 & - & - & 24 & 0 \\
\hline $6 \mathrm{~b}$ & 24 & $0 \cdot 76$ & $2 \mathrm{hr}$. & Twin 2 & $1+$ & $-\overline{0}$ & $\overline{0}$ & 24 & 0 \\
\hline 7 & 28 & $1 \cdot 37$ & $2 \mathrm{hr}$. & Poor condition at birth; IPPV; gasping respiration & $1+$ & $0 \cdot 0$ & 0 & 27 & 0 \\
\hline
\end{tabular}

HM, hyaline membrane; SR, stability ratio (normal values 0.6 ); IPPV, intermittent positive pressure ventilation; + , present; 0 , absent; $\longrightarrow$, not examined. 


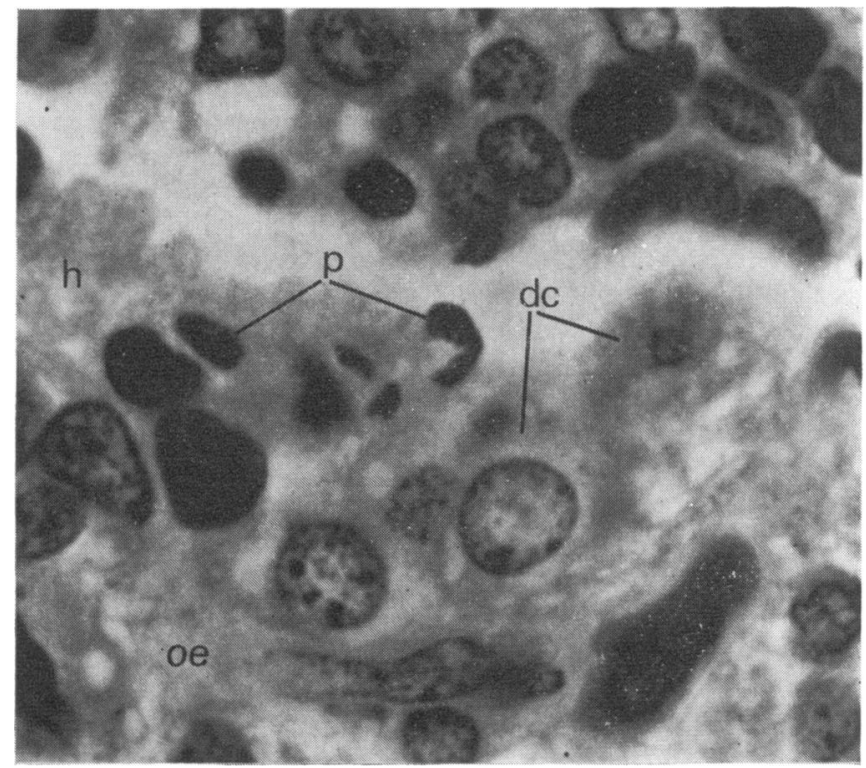

Fig. 11.-Early HMD. Same case as Fig. 10, from a different area, showing a slightly more advanced phase. There is early $H M(h)$ with pyknotic nuclear remnants $(p)$ embedded in it; desquamating cells $(d c)$ and marked interstitial oedema $(o e)$ are shown. Technique as in Fig. 9. $(\times 1,400)$.

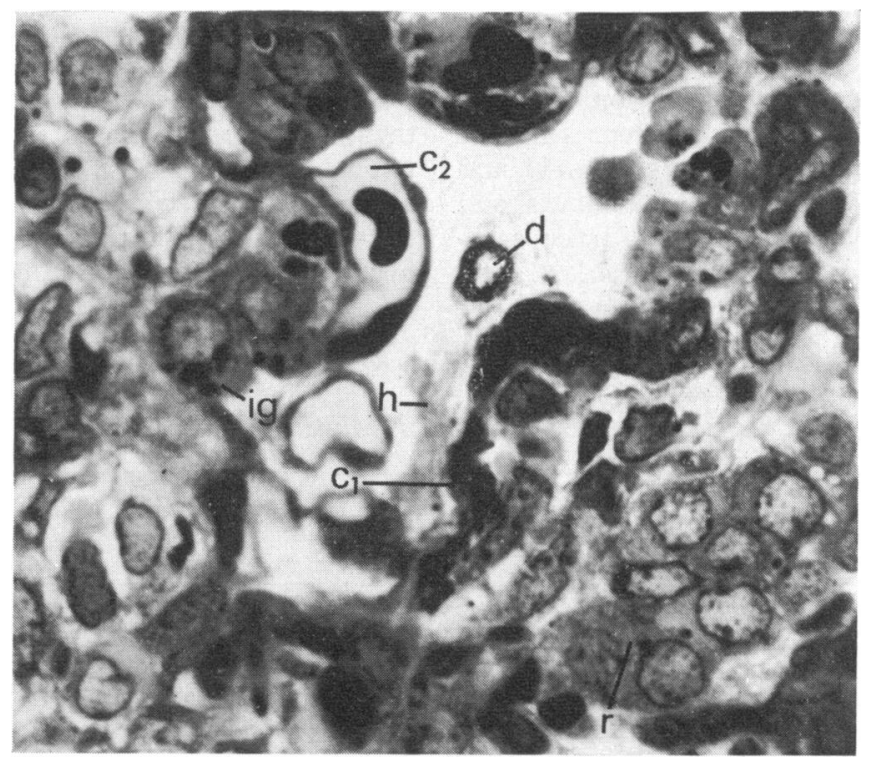

FIG. 12.-Early HMD. Lung from an infant aged 30 minutes (Case 4, Table IV, 28 weeks' gestation). On one side of the air space there is a small HM (h) in immediate apposition to a capillary filled with tightly packed red cells $\left(c_{1}\right)$. In contrast, on the opposite side of the air space there is a wide open capillary $\left(c_{2}\right)$ containing a red cell and covered by an intact flattened epithelial cell; a desquamated epithelial cell (d) lies free in the air space. There are a few intracellular granules (ig) in cuboidal cells; note cells of a rosette (r) without granules. Technique as in Fig. 2. ( $\times 1,000$.$) Surfactant abnormal.$ 


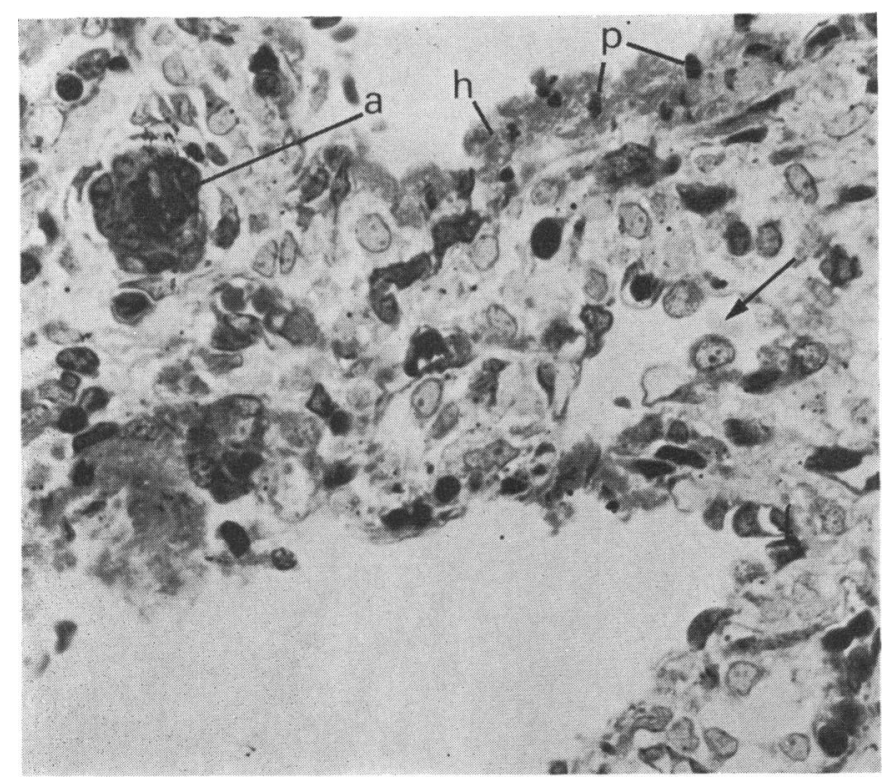

FIG. 13.- HMD intermediate stage. Lung from an infant aged 16 hours. Note hyaline membrane $(h)$ with pyknotic nuclei $(p)$ of desquamated epithelial cells embedded in it. An adjacent small air space (arrow) is unaffected. An arteriole (a) is very contracted (compare with Fig. $4 a$ and 7). There is marked interstitial oedema, and osmiophilic granules are absent. Technique as in Fig. 2. ( $\times$ 480.) Surfactant abnormal.

(Fig. 13). At the edge of the membranes local extension occurred by further desquamation of alveolar epithelial cells. Osmiophilic granules were virtually absent.

Classic picture of fully developed HMD. Specimens obtained from infants dying after 10 hours showed the characteristic widespread dilatation of alveolar ducts and pronounced atelectasis. The hyaline membranes were much more extensive in both area and number, and overlaid areas from which the epithelium was missing (Fig. 13). In some regions there were small unexpanded acini (alveolar buds) opening into the distended alveolar ducts and these were lined by a single layer of cuboidal cells. In longitudinal section these structures appeared as an oval group of cuboidal cells connected with the lumen by a short stalk of similar cells; in cross-section such acini formed rosettes around a narrow lumen, similar to those seen in normal lungs. These buds represented the lessdifferentiated epithelium and are significant in relation to the initiation of the repair phase in HMD. Dilated lymphatics and contracted arterioles were still conspicuous.

Repair phase. The lungs of almost all (10/11) infants dying after 36 hours showed evidence of a reparative phase (Table $\mathrm{V}$ ); all these infants had been treated with IPPV. The process was initially confined to very small areas, the prevailing picture remaining one of denuded alveolar surfaces covered by hyaline membranes. Signs of repair appeared in the unexpanded acini (alveolar buds or rosettes) of cuboidal cells. Many of these acini communicated with alveolar ducts that were still lined by HM. Some of the cuboidal cells in the buds were very large, and their large nuclei had a fine chromatin pattern (Fig. 14); where such cells were in direct contact with a hyaline membrane, they extended a process beneath it in an attempt to re-epithelialize the denuded wall of an alveolar duct (Fig. 14). Some of these cells were in various stages of mitotic division (Fig. 15). Osmiophilic granules $(1+)$ were seen in isolated areas, usually in cuboidal epithelial cells, but also in some large cells that appeared to be in the process of flattening. There were, however, very few capillaries in direct contact with flattened alveolar cells. In 5 of the 10 cases showing these signs of repair (Cases 1-5, Table V), $T_{\text {min. }}$ was still abnormal, these being mainly cases that had survived less than 3 days.

In the remaining 5 cases where surfactant was present (Cases 6-10, Table V), regeneration was rather more extensive. Two (Cases 6 and 7, Table V) were infants of diabetic mothers and 


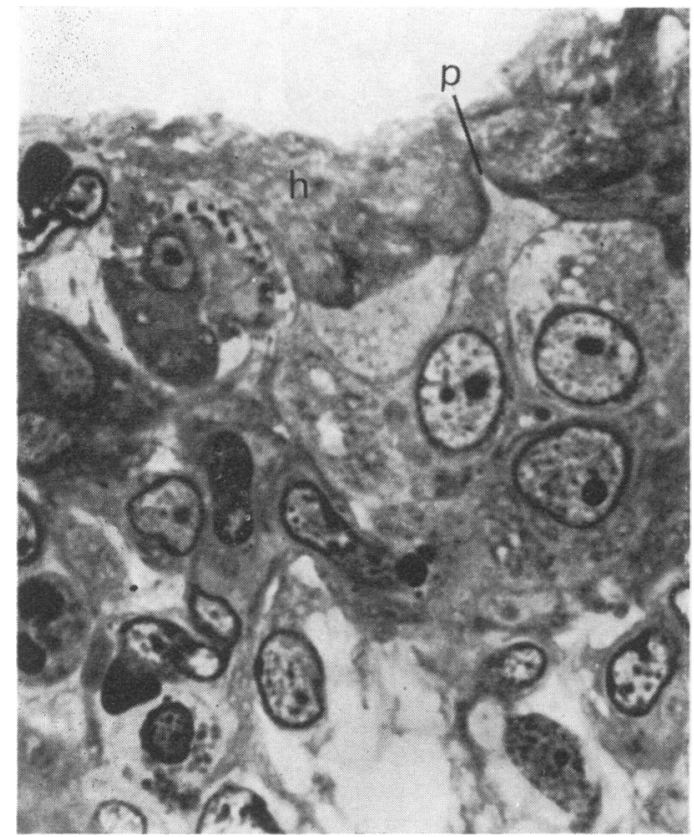

FIG. 14.-HMD repair phase. Lung from an infant aged 66 hours (Case 4, Table V). Three large epithelial cells with processes ( $p$ ) extending under the HM (h). Technique as in Fig. 9. $(\times 1,100$.$) Surfactant ab-$ normal.

survived 44 and 80 hours, respectively (the significance of this fact is discussed in Part II). These 2 cases showed many small air spaces to be lined by cuboidal cells, some of which appeared to be in course of flattening (Fig. 16). Osmiophilic granules were numerous $(2+$ and $3+)$ in the cuboidal cells, but were also present (Fig. 16) in some of the flattened cells derived from the cuboidal type. Despite these changes, there was still extensive HM formation in adjacent areas, and interstitial oedema was still marked. There were very few capillaries in apposition to flattened epithelial cells, partly because of the predominantly cuboidal epithelium, and partly because of $\mathrm{HM}$, and hence lack of epithelium, in other areas.

In contrast, the lungs from the 3 infants who lived for 5 days or longer (Cases 8,9 , and 10, Table V) showed only traces of HM in the 2 who survived 5 and 7 days and none at all in the one who survived for 5 weeks.

Late changes after HMD. The lungs from the 2 infants who survived for 1 and 5 weeks (Cases 9 and 10, Table V) showed some dilated air spaces with intervening atelectasis and also some areas of

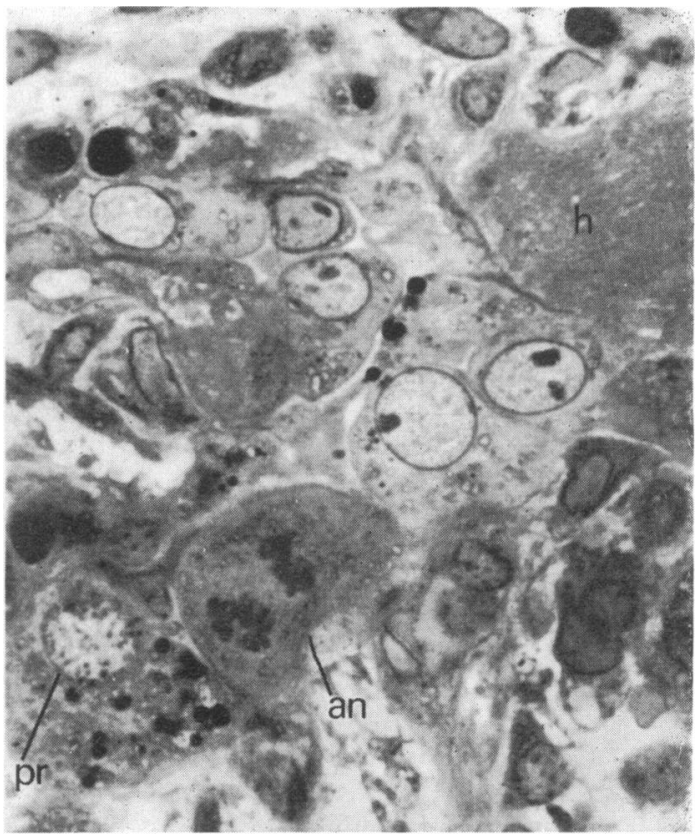

FIG. 15.-HMD, repair phase. Lung from an infant. aged 66 hours (Case 3, Table V) showing large epithelial cells in mitosis, prophase (pr), and anaphase (an). Part of a hyaline membrane $(h)$ is also shown. Technique as in Fig. 2. $(\times 1,000$. $)$ Surfactant abnormal.

bronchopneumonia. The $1 \mu$ sections, from areas not affected by bronchopneumonia, allowed a detailed study of the cellular changes which were rather similar in the 2 cases. There was less interstitial oedema than in the earlier stages, though the amount of interstitial tissue, chiefly fibroblasts, was greater than normal. A striking feature was the pleomorphism of the alveolar epithelial cells; though some were flattened, these were interspersed with cuboidal cells of varying sizes. A minority were of normal size, many were much larger than normal, due to both a large nucleus and abundant cytoplasm. There were also transitional forms of epithelial cells that formed thick squames covering areas of $30-40 \mu$ N (Fig. 17) and presumably represented large cuboidal cells in the process of flattening. There were few capillaries in close apposition to epithelial cells. Osmiophilic granules were numerous in both the large cuboidal and the thick squamous cells. Macrophages were frequent in the dilated air spaces; they were very vacuolated and contained many osmiophilic inclusions. Some free osmiophilic granules were also seen in atelectatic acini and on the walls of expanded air spaces. This 


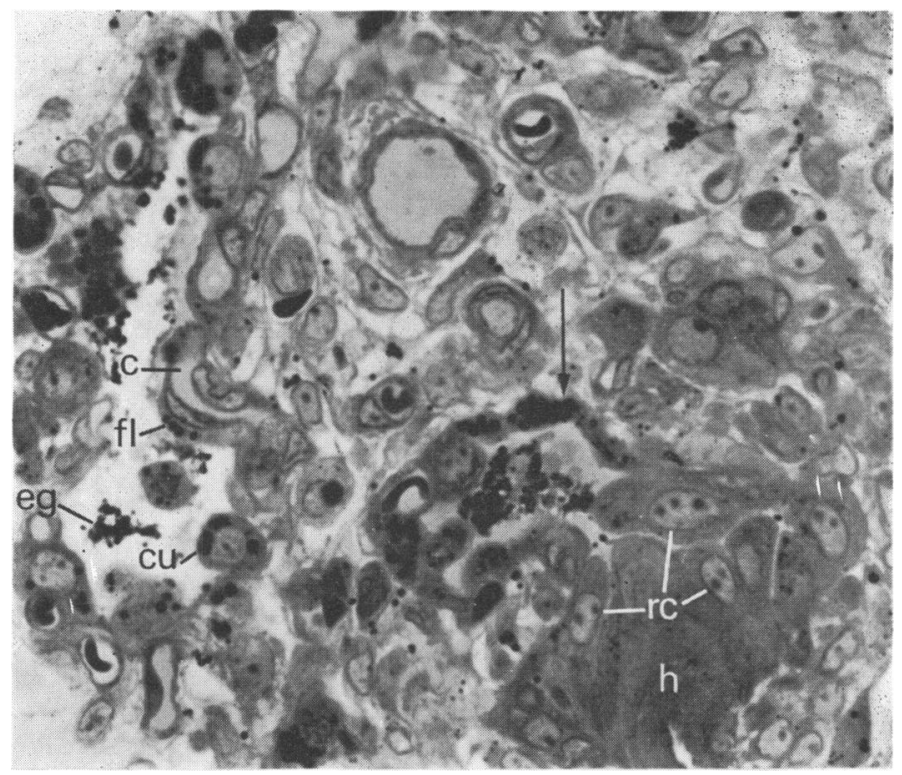

Fig. 16.-HMD repair phase. Lung section from an infant aged 80 hours (Case 7, Table V), maternal diabetes. The air space on the left is lined predominantly by cuboidal cells (cu), some with granules. A flattened cell $(f)$ overlying a capillary (c) also contains granules; some extracellular granules are present (eg). The air space in the centre (arrow) is lined mainly by abnormally thick, flattened epithelial cells with granules; regenerating epithelial cells $(r c)$ are in close proximity to a hyaline membrane (h). Technique as in Fig. 2. ( $\times 530$.$) Surfactant normal.$

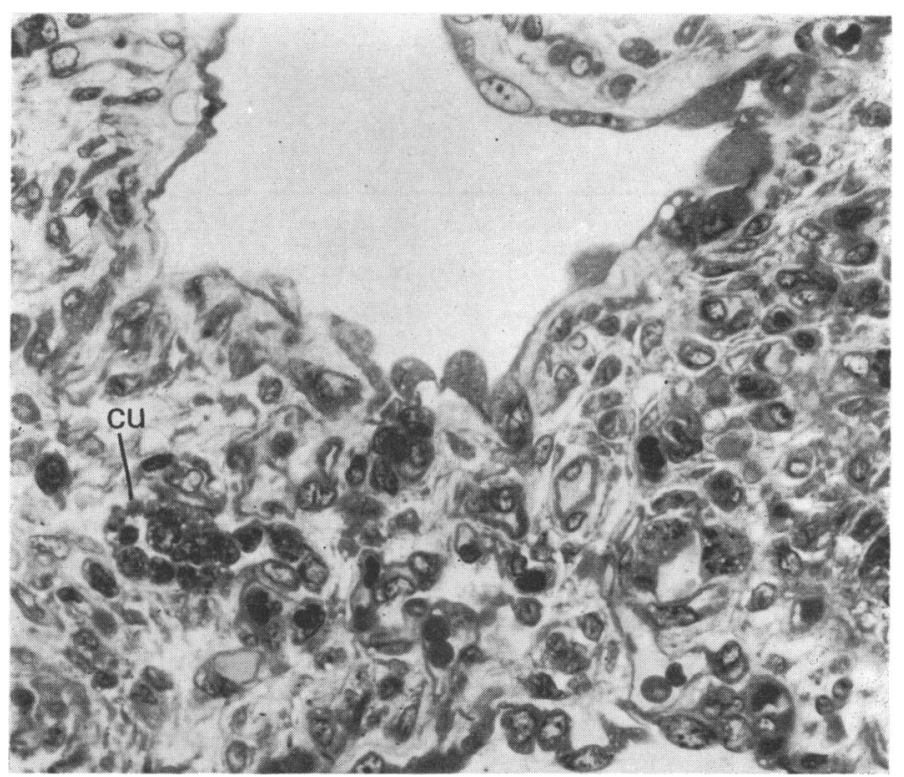

Fig. 17.-Late changes after HMD. Lung from an infant who survived 5 weeks on a respirator (Case' 10, Table V). There is increased interstitial tissue. Several small unexpanded air spaces are lined by cuboidal cells (cu). The expanded air space in the top half of the picture is lined by abnormally large, thick squames. Capillaries are sparse. Technique as in Fig. 2. ( $\times$ 380.) Surfactant normal. 
TABLE V

10 Cases of Hyaline Membrane Disease showing Signs of Repair

\begin{tabular}{|c|c|c|c|c|c|c|c|c|}
\hline $\begin{array}{l}\text { Case } \\
\text { No. }\end{array}$ & $\begin{array}{l}\text { Gest- } \\
\text { ation } \\
\text { (wk.) }\end{array}$ & $\begin{array}{l}\text { Birth- } \\
\text { weight } \\
\text { (kg.) }\end{array}$ & $\begin{array}{c}\text { Age } \\
\text { at } \\
\text { Death }\end{array}$ & Clinical & Necropsy & $\begin{array}{l}\text { Tmin. } \\
\text { (dynes/ } \\
\text { cm.) }\end{array}$ & $\begin{array}{c}\text { Granules } \\
\text { (grading } \\
0-3+\text { ) }\end{array}$ & Remarks \\
\hline 1 & 32 & $1 \cdot 36$ & $37 \mathrm{hr}$. & RDS from $1 \mathrm{hr}$; IPPV from $5 \mathrm{hr}$. & $\mathrm{HM}(3+)$ & 25 & $1+$ & $\begin{array}{l}\text { Early signs of } \\
\text { repair }\end{array}$ \\
\hline 2 & 32 & $1 \cdot 29$ & $47 \mathrm{hr}$. & $\begin{array}{l}\text { CS for placenta praevia; severe RDS; } \\
\text { IPPV from } 2 \mathrm{hr} \text {. }\end{array}$ & $\begin{array}{l}\text { HM }(2+) ; \\
\text { subarachnoid } \\
\text { haemorrhage }\end{array}$ & 27 & $1+$ & $\begin{array}{l}\text { Early signs of } \\
\text { repair }\end{array}$ \\
\hline 3 & 31 & $1 \cdot 47$ & $66 \mathrm{hr}$. & RDS at $4 \mathrm{hr}$; ; IPPV from $8 \mathrm{hr}$. & $\begin{array}{l}\text { HM }(3+) ; \\
\text { pneumo- } \\
\text { thorax; IVH }\end{array}$ & 24 & $1+$ & $\begin{array}{l}\text { Early signs of } \\
\text { repair }\end{array}$ \\
\hline 4 & 32 & $1 \cdot 72$ & $66 \mathrm{hr}$. & RDS from $1 \mathrm{hr}$; IPPV from $6 \mathrm{hr}$. & $\begin{array}{l}\mathrm{HM}(3+) \\
\text { IVH }\end{array}$ & 27 & $1+$ & $\begin{array}{l}\text { Early signs of } \\
\text { repair }\end{array}$ \\
\hline 5 & 31 & $1 \cdot 25$ & $70 \mathrm{hr}$. & $\begin{array}{l}\text { CS for severe PET; RDS from } 2 \mathrm{hr} \text {; } \\
\text { pneumothorax; IPPV from } 24 \mathrm{hr} \text {. }\end{array}$ & $\mathrm{HM}(3+)$ & 19 & $1+$ & $\begin{array}{l}\text { Early signs of } \\
\text { repair }\end{array}$ \\
\hline 6 & 35 & $3 \cdot 35$ & $44 \mathrm{hr}$. & $\begin{array}{l}\text { CS for maternal diabetes; RDS from } \\
\text { birth; IPPV from birth }\end{array}$ & $\mathrm{HM}(2+)$ & 14 & $2+$ & $\begin{array}{l}\text { Early signs of } \\
\text { repair; } \\
\text { numerous } \\
\text { granules }\end{array}$ \\
\hline 7 & 37 & $2 \cdot 23$ & $80 \mathrm{hr}$. & $\begin{array}{l}\text { CS for maternal diabetes; RDS from } \\
\text { birth; IPPV from birth }\end{array}$ & $\operatorname{HM}(3+)$ & 12 & $3+$ & $\begin{array}{l}\text { Repair; } \\
\text { numerous } \\
\text { granules }\end{array}$ \\
\hline 8 & 28 & $1 \cdot 00$ & $5 \mathrm{dy}$ & $\begin{array}{l}\text { Twin } 2 \text {; RDS from } 4 \mathrm{hr} \text {; IPPV } \\
\text { at } 4 \mathrm{dy} \text {. }\end{array}$ & $\begin{array}{l}\text { HM }(1+) ; \\
\text { intra-alveolar } \\
\text { haemorrhage }\end{array}$ & 13 & $3+$ & $\begin{array}{l}\text { Minimal resi- } \\
\text { dual } \mathrm{HM} \text {; } \\
\text { considerable } \\
\text { repair }\end{array}$ \\
\hline 9 & 36 & $2 \cdot 60$ & $7 \mathrm{dy}$ & $\begin{array}{l}\text { CS for placenta praevia; severe RDS; } \\
\text { IPPV at } 4 \text { dy.; pneumothorax }\end{array}$ & $\begin{array}{c}\text { Residual HM } \\
(1+) ; \\
\text { broncho- } \\
\text { pneumonia }\end{array}$ & 6 & $2+$ & $\begin{array}{l}\text { Minimal resi- } \\
\text { dual HM; } \\
\text { increased } \\
\text { interstitial } \\
\text { tissue; large } \\
\text { squamous } \\
\text { alveolar } \\
\text { epithelial } \\
\text { cells }\end{array}$ \\
\hline 10 & 32 & $1 \cdot 50$ & 5 wk. & $\begin{array}{l}\text { CS for severe PET; RDS from } 5 \mathrm{hr} \text {; } \\
\text { IPPV from } 27 \mathrm{hr} \text {. }\end{array}$ & $\begin{array}{l}\text { Broncho- } \\
\text { pneumonia }\end{array}$ & 4 & $2+$ & $\begin{array}{l}\text { No } H M \text {; in- } \\
\text { creased } \\
\text { interstitial } \\
\text { tissue; laree } \\
\text { squamous } \\
\text { alveolar epi- } \\
\text { thelial cells }\end{array}$ \\
\hline
\end{tabular}

RDS, respiratory distress syndrome; CS, Caesarean section; HM, hyaline membranc; IPPV, intermittent positive pressure ventilation; 0 IVH, intraventricular haemorrhage; PET, pre-eclamptic toxaemia.

pattern of cells lining the alveoli may illustrate a late repair phase of $H M D$, though the effect of oxygen must also be considered (see Discussion).

Correlation between osmiophilic granules and surfactant. Minimum surface tension was determined in 69 of the 84 cases and the results were correlated with the presence or absence of osmiophilic granules (Fig. 18). In general there was good concordance between these two sets of observations. All 13 cases belonging to Group II (livebirths without pulmonary disorders, shown as $O$ in the left upper quadrant of Fig. 18) had numerous granules and normal $T_{\min }$. values. Conversely, of the $42 \mathrm{HMD}$ cases (Group IV, O), all except 7 showed few or no granules and abnormal values for $T_{\min }$. (right lower quadrant Fig. 18). The results from 5 of the 7 exceptional cases have already been described (Cases 6-10, Table V); they showed many granules and histological $\delta$ evidence of repair. The remaining 2 exceptional $₹$ cases, one with heart failure and severe erythro- 0 blastosis, and the other with pulmonary haemorrhage and a pneumothorax, are discussed in Part II. 을

Of the 7 stillborn infants (Group I, $\times$ ), the 4 that were of more than 30 weeks' gestation had numerous or granules and normal $T_{\text {min. }}$. The remaining $3 \mathrm{~N}$ stillborn infants were very immature (26 weeks' N gestation or less), all had abundant intracellular 0 granules but gave abnormal $\mathrm{T}_{\text {min. }}$ values (right upper quadrant Fig. 18); this discordance may be related to the paucity of extracellular granules $\stackrel{\odot}{+}$ (see Discussion). The infants in Group III, $\oplus$ (pulmonary disorders other than HMD) formed a heterogeneous group and the results have already $\stackrel{\mathbb{D}}{\mathbb{D}}$ been described (Table II). 


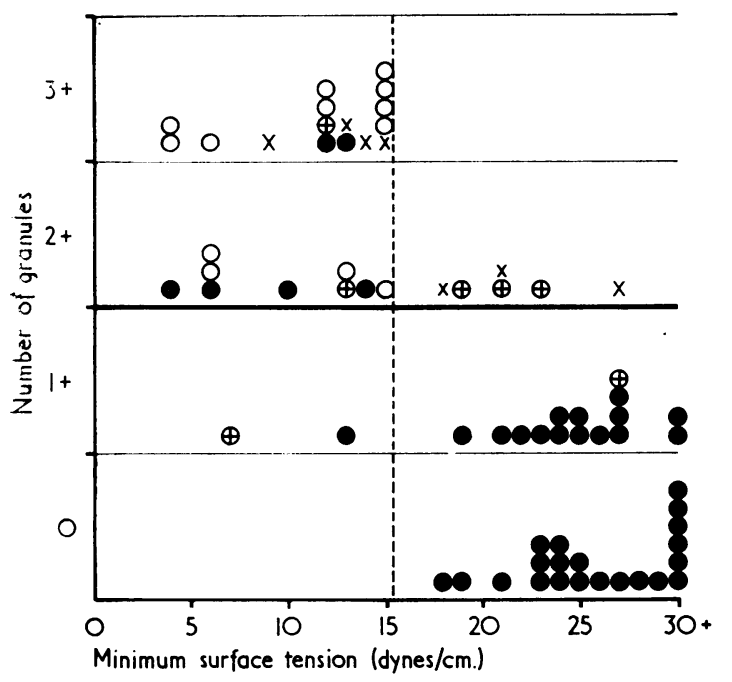

FIG. 18.-Correlation between number of osmiophilic granules and minimum surface tension in 69 infants. Symbols as in Fig. 1 . Note that with 2 exceptions, cases with abundant granules $(2$ or $3+$ ) have normal surfactant $\left(T_{\min .}<15\right.$ dynes $/ \mathrm{cm}$.).

Osmiophilic granules and gestational age. The relation between the presence or absence of granules and gestational age in the whole series of 84 infants is shown in Fig. 19. This includes the 69 cases described in the preceding section as well as the 15 cases where $T_{\min }$. was not measured.

In the most immature infants ( 20 weeks' gestation or less), granules were virtually absent in 5 of the 6 cases examined. A little later, after 23 weeks' gestation, all except 2 of the 34 cases without HMD (including 10 stillbirths) had numerous granules. Thus, if osmiophilic granules are accepted as representing production or storage of surfactant, our observations indicate that surfactant is synthesized in most fetuses from 23 weeks' gestation. The presence of HMD, as already described, was usually associated with paucity of granules (38/44 cases).

All except one of the HMD cases were of less than 37 weeks' gestation. The single exception was of interest because this was an infant of 43 weeks' gestation who had shown signs of fetal distress, and at birth was found to have aspirated massive amounts of meconium. Typical signs of RDS developed and the infant died at 25 hours. Lung sections showed HMD and numerous inhaled squames in the terminal air spaces; osmiophilic granules were absent and surfactant was deficient. This case is a rare instance of HMD in a full-term infant.

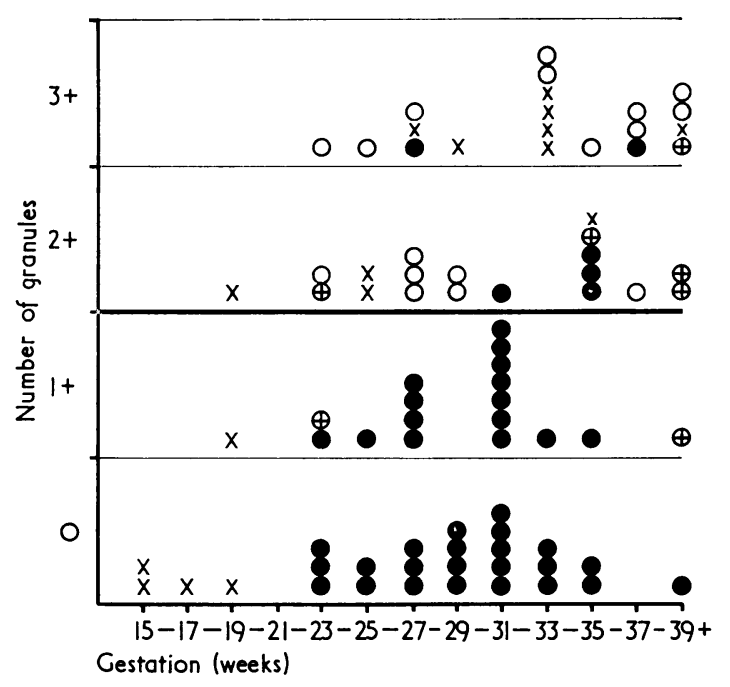

Fig. 19.-Correlation between number of osmiophilic granules and gestational age in 84 infants. Symbols as in Fig. 1. Note that granules are scanty (0 or $1+)$ only in extremely immature fetuses ( $<23$ weeks), unless there is hyaline membrane disease.

\section{Discussion}

Value of $1 \mu$ sections. Though conventional histological sections are of indisputable value, it is hard to observe cellular detail in them; at the other extreme, electron microscopy involves a more cumbersome technique and can show only a very limited field. The $1 \mu$ sections, for which the tissue is processed as for electron microscopy, combine some of the advantages of both methods; this technique proved most useful in appraising cytoplasmic inclusions and allowed recognition of the earliest cellular changes in HMD, even when the area involved extended over only two or three cells. Similarly, changes occurring during the repair phase of HMD were also clear; it was virtually impossible to follow such details in paraffin sections. These advantages of $1 \mu$ sections outweigh their sole disadvantage, the small size of the sample, but by taking blocks from different areas this disadvantage can be mitigated.

The cytoplasmic osmiophilic granules seen under the light microscope have been shown to correspond to the lamellar structures seen in electron micrographs (Buckingham, McNary, and Sommers, 1964; Balis and Conen, 1964), and in the present study the lamellar structure of the osmiophilic granules could sometimes be discerned under the light microscope.

Normal development of human lung. The 
process of maturation in the fetal lung was well visualized in $1 \mu$ sections in which it was easy to distinguish the two types of alveolar epithelial cell. The transition from a cuboidal epithelium to one composed predominantly of flattened epithelial cells was almost complete by 34 weeks' gestation; at the same time the number of capillaries bordering the alveolar walls increased, thus providing a greater area for gas exchange.

Osmiophilic granules first appeared in the cuboidal cells at about 20 weeks' gestation (in 2 out of 6 cases), and became more numerous as gestation advanced; similar observations have been made by electron microscopy (Campiche et al., 1963). Up to 26 weeks' gestation, granules were predominantly within the cells, and at this stage surfactant was not detected on the surface balance. From 30 weeks' gestation onwards, extracellular granules were frequently seen in the potential air spaces, and this was associated with normal values for $T_{\text {min. }}$ on the surface balance. Thus, normal levels of surfactant appeared in lung extracts only at about the time that osmiophilic granules were discharged from the cells.

Experimental observations by other workers are consistent with the view that extracellular granules represent surfactant that has been discharged into the alveoli. Firstly, lung liquid from mature fetal lambs contains surfactant (Adams and Fujiwara, 1963; Orzalesi et al., 1965; Humphreys et al., 1967); secondly, in the fetal rabbit it has been found that surfactant is released into the alveoli towards the end of gestation (Gluck et al., 1967); thirdly, histochemical studies have shown that extracellular phospholipid is demonstrable within the potential air spaces of fetal lung, both in the human and in the lamb (de Sa', 1965; Towers, 1968).

Cellular differentiation of the normal postnatal lung at any given gestational age appeared to proceed in much the same fashion and at the same rate as in the fetal lung.

With the onset of air breathing, surfactant is needed to form a layer overlying the alveolar epithelium, and this layer presumably requires constant replacement. Our observations provided some evidence for the continued secretion and discharge of surfactant after birth. The cuboidal cells contained granules which sometimes appeared to be discharged from the cells into the potential air spaces; also these air spaces contained many free granules which sometimes formed a coat on the alveolar surface. In this connexion it was interesting that some intracytoplasmic granules lay within a vacuole; at the point of extrusion a groove could be seen at the cell surface from which the granule emerged. This indicates that the granule is not simply 'squeezed' out of the cytoplasm, but that the membrane lining the vacuole first fuses with $\overrightarrow{\vec{F}}$ the cell membrane and then the fused membranes break down, so releasing the granule; this process has been observed in electron micrographs of adult $\overline{\overline{\bar{s}}}$. human lungs (Kuhn, 1968).

\section{Relation of osmiophilic granules to surf $-\infty$} actant. The results show that the presence of $\vec{\circ}$ surfactant, assayed by physical means, is associated $\overrightarrow{\vec{C}}$ with that of numerous osmiophilic granules. This ${ }^{\omega}$ held true in 25 of the 27 cases in which surfactant was present (Fig. 18). Conversely, in the 42 cases? where surfactant was deficient, granules also were $f$ virtually absent in all except $6 ; 4$ of these 6 were very immature infants (right upper quadrant $\vec{\sim}$ Fig. 18) where granules, though present, were ${ }_{0}^{\circ}$ largely intra- rather than extracellular. Thus the presence of osmiophilic granules was correlated with that of surfactant in $61 / 69$ cases, which is $\vec{c}$ taken as indirect evidence that the two are function- $\frac{5}{5}$ ally related. Such a conclusion is similar to that ${ }^{\Phi}$ of Kikkawa, Motoyama, and Cook (1965), who $\overrightarrow{0}$ found normal surface activity in extracts from $\triangle$ lambs' lungs when the number of inclusion- containing cuboidal cells (granular pneumonocytes) exceeded $4 \%$ of all lung tissue cells. Kikkawa, Motoyama, and Gluck (1968) carried these observations a stage further in the rabbit, where both the $\frac{\circ}{\mathbb{Q}}$ number of inclusions and the concentrations of $\stackrel{\Omega}{\vec{A}}$ lecithins increased as fetal life proceeded, dipalmitoyl lecithin being an important component of surfactant $\frac{3}{2}$ (see Part II).

In the course of the present study an experiment was made on a surface active lipoprotein fraction of $\frac{0}{\circ}$ a homogenate of normal lung from a newborn pig, prepared according to the method of Abrams (1966). This fraction was highly surface active on the $\dot{\delta}$ Wilhelmy balance, and $1 \mu$ sections of the material, processed in the same way as the lung tissue, 음 showed masses of osmiophilic granules similar to those seen in $1 \mu$ sections of normal lung. By electron microscopy, this material was shown to consist of lamellated osmiophilic structures similar of to the characteristic inclusion bodies of normal N alveolar epithelial cells. These observations agree N with those of Mendenhall (1964) who demonstrated myelin figures in washings from pig lung.

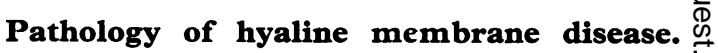
Despite the many reports on the microscopical 0 appearances of HMD, there have been few desscribing the earliest changes within the first two $\mathbb{D}$ hours of life, though these are more likely to $\frac{?}{\mathbb{D}}$ 
throw light on the pathogenesis. In the present study, the most striking and consistent features at this early stage were interstitial oedema accompanied by necrosis and desquamation of alveolar epithelial cells, either singly or in small sheets, from a thickened basement membrane. This was associated with HM formation apparent as early as the first half hour of postnatal life. The interstitial oedema and loss of epithelial cells appeared to precede the development of hyaline membranes, a conclusion that was supported by the cellular changes observed at the edge of a hyaline membrane, where sometimes a single epithelial cell with a pyknotic nucleus could be seen in the process of becoming detached from a swollen basement membrane. Our observations are very similar to those of Stahlman et al. (1964) in a study of experimental HMD in lambs.

Though epithelial damage in HMD has been observed previously, both under the light microscope (Angervall and Edstrom, 1958; Barter, 1959; Buckingham and Sommers, 1960; Lauweryns, 1965; Stowens, 1965) and by electron microscopy (Van Breemen, Neustein, and Bruns, 1957; Campiche, Prod'hom, and Gautier, 1961; Campiche, Jaccottet, and Juillard, 1962; Groniowski and Biczyskowa, 1963; Balis, Delivoria, and Conen, 1966), its importance as an early feature may not have been sufficiently well recognized. Mechanical trauma during handling of the specimen is unlikely to have affected our results, because the specimens were obtained with minimum trauma and fixed within half an hour of death, and because lungs from the 'control' groups did not show these changes.

In addition to interstitial oedema and desquamation of epithelial cells, the $1 \mu$ sections showed a fine vacuolation of the cytoplasm of capillary endothelial cells; similar findings were noted by electron microscopy (Campiche et al., 1961); this is taken as evidence of increased capillary permeability. In this connexion the state of capillaries directly beneath hyaline membranes may be relevant; they were often filled with tightly packed red cells which had a 'sludged' appearance. In contrast, capillaries bordering areas unaffected by hyaline membrane were wide open and contained plasma as well as discrete red cells like those in normal lungs. These observations suggest that plasma had leaked out of damaged capillaries in the vicinity of hyaline membranes.

Thus, the earliest cellular changes of HMD consisted of interstitial oedema and loss of epithelial cells, leading to hyaline membrane formation. Initially the process was confined to very small areas, the vast majority of epithelial cells being still intact.

In our early cases the lymphatics were dilated, which agrees with the results of other studies (WadeEvans, 1962; Lauweryns, 1965; Lauweryns, Claessens, and Boussauw, 1968; Stowens, 1965). Osmiophilic granules were virtually absent. That pulmonary arterioles appeared contracted is in accord with the histological findings in experimental HMD in lambs (Stahlman et al., 1964) and with the post-mortem injection studies of Lauweryns (1966, 1968), who found very poor filling of the pulmonary arterioles in HMD lungs.

The changes present after about 5 hours were essentially similar to those seen in the very early phase, but the hyaline membranes were more confluent and extensive, and atelectasis was more pronounced. Consequently the area available for gas exchange was severely reduced; the distended alveolar ducts, without underlying epithelium, were lined by HM, and the intervening atelectatic areas were composed largely of undifferentiated cuboidal cells. Osmiophilic granules were completely absent from areas affected by HM and occurred only occasionally in the cuboidal cells of the terminal buds.

Reparative changes in the lungs of infants with HMD who survive more than 1 to 2 days have been described previously (Boss and Craig, 1962; WadeEvans, 1962; Barter, Byrne, and Carter, 1966; Balis et al., 1966). Our observations were similar to those of Boss and Craig (1962); individual cuboidal cells with large nuclei appeared under the hyaline membranes. Some of these cells were in mitotic division, indicating an active regenerative process. In no instance did we see re-epithelialization taking place over the luminal surface of the membrane as described by Barter et al. (1966) in one of their cases, and by Balis et al. (1966) in electron micrographs.

In the present series the appearance of osmiophilic granules in the lungs of infants surviving more than 36 hours provides further evidence of regeneration, and presumably indicates recovery or maturation of the enzyme systems responsible for the production of surfactant. The progressive transformation of the large regenerating cuboidal cells to the flattened form resembled the process of differentiation in normal developing lung; this was illustrated by the fact that granules occurred not only in cuboidal epithelial cells but also in those that were flattening. Some of the newly flattened cells lining alveolar ducts, however, consisted of abnormally large thick squames with very few capillaries in apposition to them; hence the area available for gas exchange was still very small, and 
the abnormally thick epithelial cells might well cause an alveolo-capillary block.

The presence of numerous osmiophilic granules and normal values for $T_{\text {min., }}$ in some of the infants surviving more than 2 days, agrees with the observations of other workers (Gruenwald, 1964; Hawker, Reynolds and Taghizadeh, 1967; Reynolds, Roberton, and Wigglesworth, 1968). It seems possible that the increased numbers of inclusion bodies per alveolus, reported by Balis et al. (1966) in infants with HMD who survived more than 14 hours, were related to these reparative changes.

Thus, the repair process is at first patchy, with small islands of repair, surrounded by large areas where hyaline membranes are still conspicuous and alveolar ducts remain denuded of epithelial cells. If survival is prolonged, the repairing cells produce surfactant in quantities sufficient to be detected on the Wilhelmy balance. It is concluded that death at this late stage is due to factors other than surfactant deficiency.

Late changes after HMD. In the lungs of the two infants who survived 1 and 5 weeks the most striking feature was the highly abnormal epithelium lining the alveolar ducts. Many of the cells consisted of the large thick squames previously described, and there were very few capillaries in apposition to them. In many respects the epithelial changes at this late stage resembled those described by Robertson, Tunell, and Rudhe (1964) and Rowland and Newman (1969); as these authors suggested, the repair processes are probably modified by the high concentrations of oxygen used in the treatment of HMD. In this connexion, our observations on epithelial necrosis and subsequent repair in HMD resemble the changes described by Kaplan et al. (1969) and Kapanci et al. (1969) in the lungs of monkeys exposed to $100 \% \mathrm{O}_{2}$, though there was no HM formation.

Pathogenesis of hyaline membrane disease. In considering the pathogenesis of HMD from the cellular point of view, the following four factors require comment: alveolar epithelial necrosis; interstitial oedema; exudation of plasma proteins into the air spaces; and surfactant deficiency.

Alveolar epithelial cell necrosis. The loss of alveolar epithelial cells and their complete absence beneath the hyaline membranes is such a prominent feature that its importance as a factor in the pathogenesis of HMD cannot be overemphasized; this point has also been made by Barter (1959) and Barter and Maddison (1960). Moreover the destruction of alveolar epithelium was a consistent finding even in our early cases, and preceded the $\frac{O}{\overline{\frac{S}{0}}}$ development of hyaline membranes. Exactly the? same process occurred in the more advanced $\overrightarrow{\vec{F}}$ stages, though the area involved was much greater. $\frac{\overrightarrow{0}}{0}$ This implies an increasing destruction of the gas- $\frac{C}{\sigma}$ exchanging surfaces. Together with the atelectasis, this sequence of events is entirely compatible with $\overrightarrow{\mathbb{D}}$ the clinical course of the disease in fatal cases.

The necrosis does not involve either the under- $-\infty$ lying stroma or the undifferentiated terminal buds of $\vec{O}$ cuboidal cells from which re-epithelialization occurs $\vec{A}$ in the later stages of the disease. Furthermore, if $\vec{\sigma}$ the same sequence of events takes place in the lungs of infants who recover from HMD, the factors? causing the initial cell loss must be transient to $\mathrm{G}$ judge from the evidence of cellular repair starting on $i$ the second day of the disease.

The cause of the epithelial cell death is not clear, $\underset{\infty}{\sim}$ but it may be related to the interstitial oedema as 0

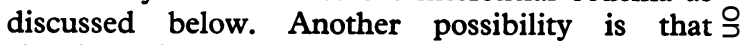
alveolar epithelial cells are particularly susceptible to injury if they are deprived of a coat of surfactant on their free surface.

Interstitial oedema. Marked perivascular and $\vec{\varphi}$ interstitial oedema was a consistent feature at all stages of the disease, even in the early phase when $\square$ only minute areas of hyaline membrane were discernible.

The oedema might be the net result of two factors: first, an impaired clearance of lung liquid by the $\frac{\circ}{\mathbb{D}}$ lymphatics after birth (Normand et al., 1968), $\stackrel{\varrho}{\vec{t}}$ and secondly, an increased capillary permeability. Both these factors might result from a high alveolar retractive pressure due to surfactant deficiency and the consequent atelectasis (Boston et al., 1965). (See also Part II, Fig. 7.)

The interstitial oedema might be responsible for ? the desquamation of alveolar epithelial cells, by levering them off their swollen basement membrane; a similar suggestion was made by Stowens (1965). $\frac{0}{3}$ In the present study, single epithelial cells or groups of them were seen in the process of being lifted off $\frac{1}{5}$ the basement membrane, both in the early stages $\frac{D}{0}$ (Fig. $10 \mathrm{~b}$ and 11) and at the edge of established hyaline membranes in the cases that survived longer. N

Exudation of plasma proteins. It is generally $N$ agreed that HMD is associated with a leakage of plasma proteins into the air spaces (Gitlin and Craig, 1956; Duran-Jorda, Holzel, and Patterson, 1956; Gajl-Peczalska, 1964). If, however, this were merely a transudation, as in pulmonary oedema due to heart failure, it would not be associated with alveolar epithelial necrosis, and the alveoli would become filled with fluid. We have observed that the hyaline membranes are strictly 
confined to areas where the alveolar epithelium is disrupted, and furthermore, capillaries underlying hyaline membranes appeared to be damaged which would facilitate the transfer of fibrinogen from the plasma. The lung is known to be a rich source of thromboplastin, and this could account for the conversion of fibrinogen to fibrin in the membranes. It is concluded that the mechanism for hyaline membrane formation is a process of exudation through a superficial 'wound' of the denuded alveolar surface.

Surfactant deficiency. The cause of the surfactant deficiency is still uncertain and is discussed in more detail in Part II, but some of our observations on the cellular changes in HMD may be relevant; in the most immature infants with HMD (24 weeks), osmiophilic granules were virtually absent, even during the first hour of life. By contrast, infants of similar gestational age who died without HMD usually had numerous granules and normal surfactant. It can therefore be postulated that in the HMD cases, inadequate amounts of surfactant were available, owing to immaturity of the synthesizing enzyme systems.

There is a widespread view that the initiating factor in the chain of events leading to surfactant deficiency and HMD is pulmonary arteriolar vasoconstriction due to asphyxia (Chu et al., 1965). Reynolds et al. (1968) have put forward cogent arguments against this opinion, and our observations also provide some evidence against asphyxia being of crucial importance. In this series there were 5 full-term infants 12-48 hours of age who died after severe birth asphyxia. 4 of these (Cases 3-6, Table II) did not have HMD, and in 3, osmiophilic granules were plentiful; there was no desquamation of alveolar epithelial cells and interstitial oedema was minimal. Only in 1 case with severe birth asphyxia did HMD develop.

Furthermore, during the repair phase of HMD, osmiophilic granules appeared and surfactant could sometimes be found at a time when the infants had been grossly hypoxic during life with large right-to-left shunts.

These observations would argue against the contention that damage to alveolar epithelium and surfactant deficiency are caused primarily by a low pulmonary blood flow, and it is concluded that asphyxia plays only a contributory role in the pathogenesis of HMD. A similar conclusion was reached by Reynolds et al. (1965) from a study of experimental HMD in lambs.

We are most grateful to Dame Honor B. Fell, F.R.S., Director of the Strangeways Research Laboratory, for her continued interest and advice. We would like to thank the nursing staff of the Cambridge Maternity Hospital for their unfailing co-operation; Mrs. Jennifer Routledge and Miss Patricia Pomeroy for skilled technical assistance; and Martin Applin and Roger Flemans for expert help with photography.

G.G. was supported by grants from the Medical Research Council, and Action for the Crippled Child.

\section{REFERENCES}

Abrams, M. E. (1966). Isolation and quantitative estimation of pulmonary surface-active lipoprotein. Fournal of Applied Physiology, 21, 718.

Adams, F. H., and Fujiwara, T. (1963). Surfactant in fetal lamb tracheal fluid. Fournal of Pediatrics, 63, 537.

Angervall, L., and Edstrom, J. E. (1958). The occurrence of deoxyribonucleic acid in pulmonary hyaline membranes of the newborn infant. Acta Pathologica et Microbiologica Scandinavica, 44, 1 .

Balis, J. U., and Conen, P. E. (1964). The role of alveolar inclusion bodies in the developing lung. Laboratory Investigation, 13 , 1215.

—, Delivoria, M., and Conen, P. E. (1966). Maturation of postnatal human lung and the idiopathic respiratory distress syndrome. Laboratory Investigation, 15, 530.

Barter, R. A. (1959). The neonatal pulmonary hyaline membrane. Lancet, 2, 160.

—, Byrne, M. J., and Carter, R. F. (1966). Pulmonary hyaline membrane: late results of injury to the lung linings. Archives of Disease in Childhood, 41, 489.

pulmonary hyaline membrane. Archives of Disease in Childhood, 35, 460.

Boss, J. H., and Craig, J. M. (1962). Reparative phenomena in lungs of neonates with hyaline membranes. Pediatrics, 29, 890.

Boston, R. W., Humphreys, P. W., Reynolds, E. O. R., and Strang, L. B. (1965). Lymph-flow and clearance of liquid from the lungs of the foetal lamb. Lancet, 2, 473.

Buckingham, S., McNary, W. F., Jr., and Sommers, S. C. (1964). Pulmonary alveolar cell inclusions: their development in the rat. Science, 145, 1192.

, and Sommers, S. C. (1960). Pulmonary hyaline membranes: a study of the infant disease and experimental hyaline membranes induced pharmacologically. American fournal of Diseases of Children, 99, 216.

Campiche, M. A., Gautier, A., Hernandez, E. I., and Reymond, A. (1963). An electron microscope study of the fetal development of human lung. Pediatrics, 32, 976.

, Jaccottet, M., and Juillard, E. (1962). La pneumonose à membranes hyalines: observations au microscope électronique. Annales Paediatrici, 199, 74.

- - Prod'hom, S., and Gautier, A. (1961). Etude au microscope électronique du poumon de prématurés morts en détresse respiratoire. Annales Paediatrici, 196, 81.

Chu, J., Clements, J. A., Cotton, E., Klaus, M. H., Sweet, A. Y., Thomas, M. A., and Tooley, W. H. (1965). The pulmonary hypoperfusion syndrome. Pediatrics, 35, 733.

de Sa', D. J. (1965). Microscopy of the alveolar lining layer in newborn infants. Lancet, 1, 1369.

Duran-Jorda, F., Holzel, A., and Patterson, W. H. (1956). A histochemical study of pulmonary hyaline membrane. Archives of Disease in Childhood, 31, 113.

Estable-Puig, J. F., Bauer, W. C., and Blumberg, J. M. (1965). Paraphenylenediamine staining of osmium-fixed plasticembedded tissue for light and phase miscroscopy. fournal of Neuropathology and Experimental Neurology, 24, 531.

Gajl-Peczalska, K. (1964). Plasma protein composition of hyaline membrane in the newborn as studied by immunofluorescence. Archives of Disease in Childhood, 39, 226.

Gandy, G., Bradbrooke, J. G., Naidoo, B. T., and Gairdner, D. (1968). Comparison of methods for evaluating surface properties of lung in perinatal period. Archives of Disease in Childhood, 43, 8.

Gitlin, D., and Craig, J. M. (1956). The nature of the hyaline membrane in asphyxia of the newborn. Pediatrics, 17, 64. 
Gluck, L., Motoyama, E. K., Smits, H. L., and Kulovich, M. V. (1967). The biochemical development of surface activity in mammalian lung. I. The surface-active phospholipids; the separation and distribution of surface-active lecithin in the lung of the developing rabbit fetus. Pediatric Research, 1, 237.

Groniowski, J., and Biczyskowa, W. (1963). The fine structure of the lungs in the course of hyaline membrane disease of the newborn infant. Biologia Neonatorum, 5, 113.

Gruenwald, P. (1964). The course of the respiratory distress syndrome of newborn infants, as indicated by poor stability of pulmonary expansion. Acta Paediatrica, 53, 470.

Hawker, J. M., Reynolds, E. O. R., and Taghizadeh, A. (1967) Pulmonary surface tension and pathological changes in infants dying after respirator treatment of severe hyaline membrane disease. Lancet, 2, 75.

Humphreys, P. W., Normand, I. C. S., Reynolds, E. O. R., and Strang, L. B. (1967). Pulmonary lymph flow and the uptake of liquid from the lungs of the lamb at the start of breathing. fournal of Physiology, 193, 1.

Kapanci, Y., Weibel, E. R., Kaplan, H. P., and Robinson, F. R. (1969). Pathogenesis and reversibility of the pulmonary lesions of oxygen toxicity in monkeys. II. Ultrastructural and morphometric studies. Laboratory Investigation, 20, 101.

Kaplan, H. P., Robinson, F. R., Kapanci, Y., and Weibel, E. R. (1969). Pathogenesis and reversibility of the pulmonary lesions of oxygen toxicity in monkeys. I. Clinical and light microscopic studies. Laboratory Investigation, 20, 94.

Karrer, H. E. (1956). The ultrastructure of mouse lung. General architecture of capillary and alveolar walls. fournal of Biophysical and Biochemical Cytology, 2, 241.

Kikkawa, Y., Motoyama, E. K., and Cook, C. D. (1965). The ultrastructure of the lungs of lambs. American fournal of Pathology, 47, 877.

- _ newborn rabbits. Morphologic, biochemical, and surface physical development. American fournal of Putholog $v, 52,177$.

Kuhn, C. (1968). Cytochemistry of pulmonary alveolar epithelial cells. American Fournal of Pathology, 53, 809.

Lauweryns, J. M. (1965). Hyaline membrane disease: a pathological study of 55 infants. Archives of Disease in Childhood, 40, 618 .

- (1966). Pulmonary arterial vasculature in neonatal hyaline membrane disease. Science, 153, 1275.

- (1968). Pulmonary venous vasculature in neonatal hyaline membrane disease. Science, 160, 190.

_, Claessens, S., and Boussauw, L. (1968). The pulmonary lymphatics in neonatal hyaline membrane disease. Pediatrics, 41, 917.

Macklin, C. C. (1954). The pulmonary alveolar mucoid film and the pneumonocytes. Lancet, 1, 1099.

Mendenhall, R. M. (1964). Surface lining of lung alveoli as a $\overrightarrow{\vec{C}}$ structure. Nature (London), 201, 713.

Normand, I. C. S., Reynolds, E. O. R., Strang, L. B., and Wigglesworth, J. S. (1968). Flow and protein concentration of lymph from lungs of lambs developing hyaline membrane disease. Archives of Disease in Childhood, 43, 334.

Orzalesi, M. M., Motoyama, E. K., Jacobson, H. N., Kikkawa, Y., 를 Reynolds, E. O. R., and Cook, C. D. (1965). The development of the lungs of lambs. Pediatrics, 35, 373.

Reynolds, E. O. R., Jacobson, H. N., Motoyama, E. K., Kikkawa, $\overrightarrow{0}$ Y., Craig, J. M., Orzalesi, M. M., and Cook, C. D. (1965). The :effect of immaturity and prenatal asphyxia on the lungs and $\vec{c}$ pulmonary function of newborn lambs: the experimental $\vec{\omega}$ production of respiratory distress. Pediatrics, 35, 382.

production of reston, N. R. C., and Wigglesworth, J. S. (1968). Hyaline 尺ొ membrane disease, respiratory distress, and surfactant defi- ? ciency. Pediatrics, 42, 758.

Robertson, B., Tunell, R., and Rudhe, U. (1964). Late stages of pulmonary hyaline membranes of the newborn. Acta Paediatrica, 53, 433.

Rowland, R., and Newman, C. G. H. (1969). Pulmonary complica- iv tions of oxygen therapy. Fournal of Clinical Pathology, 22, 192.

Stahlman, M., Lequire, V. S., Young, W. C., Merrill, R. E., 음 Birmingham, R. T., Payne, G. A., and Gray, J. (1964). Pathophysiology of respiratory distress in newborn lambs. American Fournal of Diseases of Children, 108, 375.

Stowens, D. (1965). Hyaline membrane disease: morbid anatomy, hypothesis of its pathogenesis, and suggested method of treatment. American fournal of Clinical Pathology, 44, 259.

Towers, B. (1968). The fetal and neonatal lung. In Biology of Gestation, vol. 2, p. 189. Ed. by N. S. Assali. Academic Press, ? New York and London.

Van Breemen, V. L., Neustein, H. B., and Bruns, P. D. (1957). Pulmonary hyaline membranes studied with the electron microscope. American Fournal of Pathology, 33, 769.

Wade-Evans, T. (1962). The formation of hyaline membranes in the newborn baby. Archives of Disease in Childhood, 37, 470.

Correspondence to Dr. G. Gandy, Cambridge Maternity Hospital, Mill Road, Cambridge. 